\title{
Purinergic modulation of the immune response to infections
}

\author{
Natalia Eberhardt ${ }^{1,2} \oplus$. Gastón Bergero ${ }^{1} \cdot$ Yanina L. Mazzocco Mariotta ${ }^{1} \cdot$ M. Pilar Aoki $\left.^{1,3}\right]$
}

Received: 27 September 2021 / Accepted: 17 December 2021 / Published online: 8 January 2022

(c) The Author(s), under exclusive licence to Springer Nature B.V. 2022

\begin{abstract}
Infectious diseases are caused by the invasion of pathogenic microorganisms such as fungi, bacteria, viruses, and parasites. After infection, disease progression relies on the complex interplay between the host immune response and the microorganism evasion strategies. The host's survival depends on its ability to mount an efficient protective anti-microbial response to accomplish pathogen clearance while simultaneously preventing tissue injury by keeping under control the excessive inflammatory process. The purinergic system has the dual function of regulating the immune response and triggering effector antimicrobial mechanisms. This review provides an overview of the current knowledge of the modulation of innate and adaptive immunity driven by the purinergic system during parasitic, bacterial and viral infections.
\end{abstract}

Keywords Purinergic system · Infectious diseases $\cdot$ Immune response $\cdot$ ATP $\cdot$ Adenosine

\section{Abbreviations}

ADA

ADO

Adenosine deaminase

ADORA

Adenosine

ADP

AIDS

AMP

ART

ATP

$\mathrm{BM}$

CK-MB

Adenosine receptors

Adenosine diphosphate

Acquired immunodeficiency syndrome

Adenosine monophosphate

Antiretroviral therapies

Adenosine triphosphate

Bone marrow

Creatine kinase-myocardial band

M. Pilar Aoki

pilar.aoki@unc.edu.ar

Natalia Eberhardt

natalia.eberhardt@nyulangone.org; neberhardt@unc.edu.ar

Gastón Bergero

gbergero@unc.edu.ar

Yanina L. Mazzocco Mariotta

ymazzocco@unc.edu.ar

1 Centro de Investigaciones en Bioquímica Clínica e Inmunología (CIBICI), Consejo Nacional de Investigaciones

Científicas y Tecnológicas (CONICET) - Departamento de Bioquímica Clínica, Facultad de Ciencias Químicas, Universidad Nacional de Córdoba, Córdoba, Argentina

2 Present Address: Department of Medicine, Leon H. Charney Division of Cardiology, New York University School of Medicine, New York, USA

3 Haya de La Torre and Medina Allende, Ciudad Universitaria, CP 5000 Córdoba, Argentina

$\begin{array}{ll}\text { CLP } & \text { Cecal ligation and puncture } \\ \text { CMV } & \text { Cytomegalovirus } \\ \text { CRS } & \text { Cytokines release syndrome } \\ \text { DENV } & \text { Dengue virus } \\ \text { EBV } & \text { Epstein-Barr virus } \\ \text { E-NTPDases } & \begin{array}{l}\text { Ectonucleoside triphosphate } \\ \text { diphosphohydrolases }\end{array} \\ \text { HBV } & \text { Hepatitis B virus } \\ \text { HCC } & \text { Hepatocellular carcinoma } \\ \text { HCV } & \text { Hepatitis C virus } \\ \text { HDV } & \text { Hepatitis D virus } \\ \text { HIV } & \text { Human immunodeficiency virus } \\ \text { HPV } & \text { Human papillomavirus } \\ \text { IECs } & \text { Intestinal epithelial cells } \\ \text { IFN } & \text { Interferon } \\ \text { IL } & \text { Interleukin } \\ \text { iNOS } & \text { Inducible nitric oxide synthase } \\ \text { KO } & \text { Knock-out } \\ \text { MDSCs } & \text { Myeloid-derived suppressor cells } \\ \text { NECA } & \text { 5'-N-ethylcarboxamide adenosine } \\ \text { NETs } & \text { Neutrophil extracellular traps } \\ \text { NO } & \text { Nitric oxide } \\ \text { PAMPs } & \text { Pathogen-associated molecular patterns } \\ \text { Tfh } & \text { T follicular helper cells } \\ \text { TLR } & \text { Toll-like receptors } \\ \text { TNF } & \text { Tumor necrosis factor } \\ \text { Tr1 } & \text { Type-1 regulatory T cells } \\ \text { Treg } & \text { Regulatory T cell } \\ & \\ & \end{array}$


VL

Visceral leishmaniasis

WT

Wild-type

\section{Introduction}

The immune response is a biological process to protect the host from infections. A healthy immune system can recognize and differentiate self-antigens and antigens belonging to microorganisms such as parasites, fungi, viruses and bacteria. As such, immunity pursues pathogen clearance and preserves tissue homeostasis through a wide range of complex networks that involve cellular and humoral components with regulatory feedback systems [1]. A variety of inflammatory and suppressive responses are generated following infection or injury to restore the homeostatic conditions. The host exerts intrinsic control between both responses to achieve pathogen elimination while simultaneously preventing collateral damage.

The purinergic system has the dual function of modulating the host immune response and triggering effector mechanisms [2-4]. Adenosine triphosphate (ATP), adenosine (ADO) and other purine metabolites are the major representative mediators of purinergic signaling cascades (Fig. 1) [5]. The release of intracellular ATP in response to hypoxic or inflamed conditions by intact, activated or dying cells is the first step of purinergic signaling [6]. Extracellular ATP can activate and initiate a purinergic signaling cascade through purinergic receptors, a concept introduced by Geoffrey Burnstock in the early 1970 [7]. Extracellular ATP triggers multiple immune effector functions to inhibit infections and is primarily a pro-inflammatory metabolite [8], which can act at both paracrine and autocrine level activating two types of $\mathrm{P} 2$ receptors [9]. P2X receptors are plasma membrane channels that mediate influx or efflux of various cations, such as $\mathrm{Ca}^{+2}$. P2Y are G-protein-coupled receptors that modulate signaling events of secondary messengers [10]. The life span of extracellular ATP is determined by purinergic ectoenzymes that coordinate a two-step enzymatic process of ATP hydrolysis into the potent anti-inflammatory ADO. The family of ectonucleoside triphosphate diphosphohydrolases (E-NTPDases), the largest family of ectonucleotidases consisting of eight E-NTPDases, hydrolyze nucleotide triphosphates (e.g., ATP) and diphosphates (e.g., adenosine diphosphate ADP) to generate nucleotide monophosphates (e.g., AMP). The most studied is the ENTPD1, also known as ecto-apyrase CD39 [11]. The second and limiting enzymatic step for ADO production involves converting AMP mediated by 5 '-ectonucleotidase (NT5E), commonly known as CD73. Extracellular ADO exerts a central role in restricting tissue inflammation, as it is considered a retaliatory metabolite that inhibits ATPdriven pro-inflammatory effects due to its recognition by P1 receptors [12]. There are 4 types of purinergic G-coupled receptors ADO receptors (ADORA): ADORA1, ADORA2a, ADORA2b and ADORA3, which bind ADO with different affinity and exert various functions. It should be noted that ADO half-life in the extracellular compartment is extremely short, as it is metabolized by adenosine deaminase (ADA) between 15 seconds to a couple of minutes, depending on the host [13].

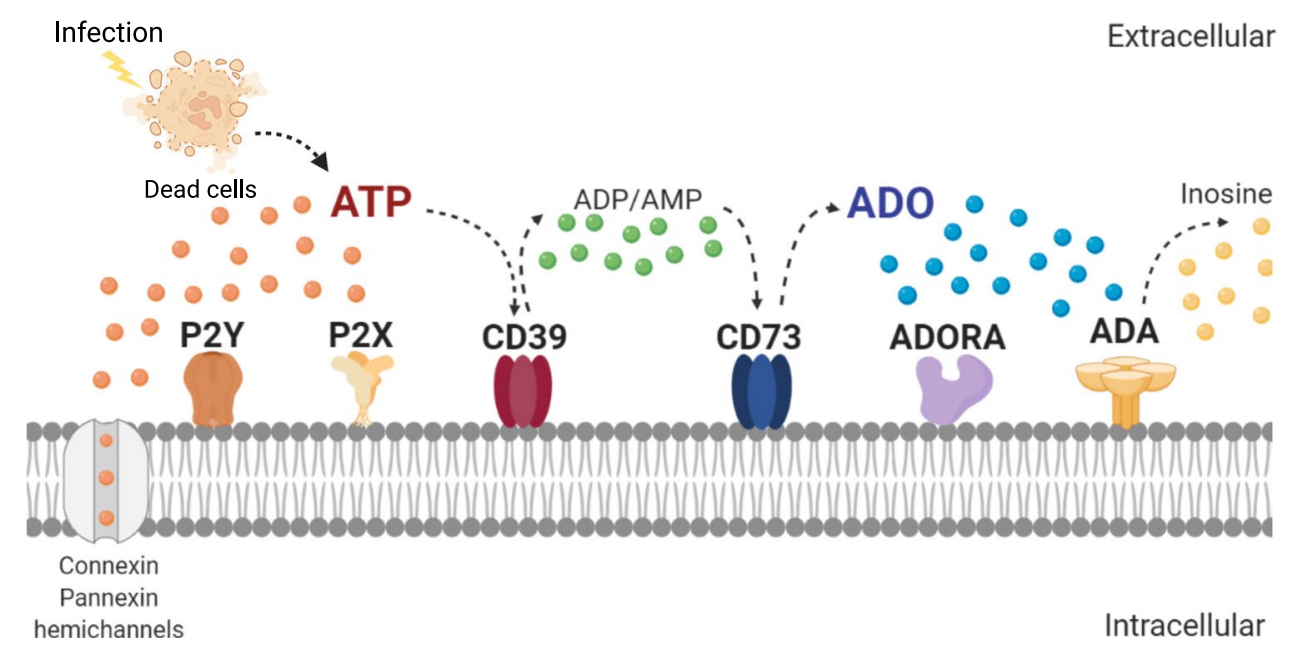

Fig. 1 Components of the purinergic signaling pathway. Stimulation of specific surface immune cell receptors that recognize pathogens, antigens, cytokines or chemokines triggers the release of ATP through connexin or pannexin hemichannels. ATP in the extracellular space can stimulate the $\mathrm{P} 2 \mathrm{X}$ or $\mathrm{P} 2 \mathrm{Y}$ receptors to trigger an inflammatory response. The ecto-apyrase (CD39) catalyzes the hydrolysis of ATP to ADP/AMP, and consecutively, the enzyme 5'-ectonucleotidase (CD73) catalyzes the limiting step of conversion to adenosine (ADO), which is the ligand for $\mathrm{P} 1$ receptors promoting anti-inflammatory responses. ADO can be removed by nucleoside transporters, which facilitates its cellular absorption, or by adenosine deaminase (ADA), which converts ADO to inosine 
Although dampening inflammation is beneficial for preventing tissue damage ensuring host survival, it may also be detrimental for pathogen clearance after infection. The failure in the fine control of the immune response balance can alter pro-inflammatory/regulatory microenvironments, which eventually lead to pathophysiological conditions, such as chronic infectious diseases. In this regard, protective immune responses in some instances are the countermeasures that prevent disease, but not necessarily infection. Besides immune cells, several pathogens also utilize or possess purinergic machinery to foster their persistence or disrupt the host immune response.

\section{Purinergic modulation of immune response}

Purinergic signaling involves various mechanisms used by innate and adaptive immune cells to modulate their functions and adapt to local microenvironment [14]. During inflammatory conditions, the purinergic signaling pathways are activated to initiate immune cell chemotaxis toward inflamed tissue and fine-tuned control local inflammation. Initially, ATP release to the extracellular environment is mediated by pannexin or connexin hemichannels to regulate cell functions in an autocrine or paracrine manner [8]. The first cell to arrive at the inflammation site is the neutrophil, which employ an extracellular ATP-dependent mechanism to generate a chemotactic gradient and orientate its migration [15, 16]. Remarkably, the purinergic system regulates many effector functions of neutrophils, such as phagocytosis, oxidative burst, degranulation and neutrophil extracellular traps (NETs) formation [17]. After its death, apoptotic neutrophils release ATP to stimulate mononuclear phagocytic cell influx and promote engulfment and clearance functions [18]. The local microenvironment composed by ATP and the consequent metabolization to ADO by CD39 and CD73 ectoenzymes influence host-pathogen interaction by metabolic reprogramming of the innate and adaptive immune cells $[19,20]$. Among myeloid cells, macrophages are the most studied cells in terms of phenotype and function modified by the purinergic system [21]. Several studies reported that ADO can reprogram monocyte and macrophages from a microbicidal and pro-inflammatory profile (classically activated-M1-like phenotype) to an alternatively activated and anti-inflammatory (M2-like) phenotype via ADORA receptors [22]. Macrophages have high plasticity capacity and can undergo profound metabolic modifications when recognizing pathogen-associated molecular patterns (PAMPs) mediated by Toll-like receptors (TLR)-stimulation. Indeed, macrophages induce the production of ATP and rapid extracellular degradation to control their activation state in an autoregulatory mechanism [23]. CD39 deficiency in macrophages promotes a sustained inflammatory activation state and inhibits the switch to an immunosuppressive phenotype [24]. ADO stimuli of ADORA2a and ADORA2b receptors in macrophages increase the expression of M2 macrophage markers and diminish the expression of inflammatory genes $[25,26]$. In addition, ADO has been reported to induce the production of anti-inflammatory cytokines such as IL-10 and VEGF and suppress the production of proinflammatory cytokines (TNF- $\alpha$ and IL-6) by macrophage [27]. ADORA2b-inhibited and IFN- $\gamma$-treated macrophages extend their microbicidal and pro-inflammatory activities with increased IL-12 and TNF- $\alpha$ production in response to TLR stimulation [28].

Regarding adaptive immunity, the purinergic system has been reported as a modulator of the induction of different $\mathrm{T}$ helper profiles. $\mathrm{T}$ cell antigen receptor (TCR) ligation initiates $\mathrm{T}$ cell activation by increasing cytosolic calcium and the release of ATP via pannexin-1 mechanism. Extracellular ATP acts in an autocrine manner via P2X receptors to induce IL-2 production and cell proliferation. The absence of this purinergic pathway leads to $\mathrm{T}$ cell anergy with increased expression of anergy-associated genes 2 and 3 (Erg2 and Erg3) [29]. In line with this, ATP-dependent activation of P2X7R inhibits suppressive functions of $T$ regulatory (Treg) cells, inducing the Th17 differentiation [30]. Furthermore, P2X7R plays a role in generating longlived memory $\mathrm{CD} 8+\mathrm{T}$ cells, regulating their mitochondrial fitness and promoting the differentiation and survival of resident memory subsets via TGF- $\beta$ signaling $[31,32]$. On the other hand, ADORA2a receptor signal inhibits Th1 cell generation and IFN- $\gamma$ production, triggering the induction of FoxP $3+$ Treg cell subset and the production of TGF- $\beta[33$, 34]. ATP catabolism and generation of retaliatory metabolite ADO is a typical suppression mechanism of regulatory cells involving Treg, type-1 regulatory ( $\operatorname{Tr} 1) \mathrm{T}$ cells and myeloidderived suppressor cells (MDSCs) [35, 36]. These regulatory cells express CD39 and CD73 to abrogate ATP-related effects and enable the inhibitory properties [37-40].

\section{Relevance of the purinergic immune modulation in infectious diseases}

The purinergic system has acquired a fundamental role in cellular and tissue microenvironment modulation upon damage to promote system regeneration and homeostasis $[2,3]$. Remarkably, immune cell regulation mediated by purinergic signaling pathways has taken great therapeutic relevance in carcinogenic and inflammatory processes. The role of purinergic signaling in the immunomodulation in these contexts was reviewed elsewhere [41, 42]. Several recent studies suggest that a precisely orchestrated purinergic mechanism defines effector functions on immune cells and, thus, the result of host-microbe interaction $[3,11,14$, 
43, 44]. However, a clear understanding of its relevance in the pathogenesis of infectious diseases and the possible therapeutic approaches still requires future research. Here, we focused on understanding the regulation of immune cell effector functions driven by purinergic signaling in the context of parasitic, viral and bacterial infections and their effects on pathogen clearance. This review aims to comprehensively summarize the current literature regarding the purinergic modulation of the immune response to pathogens and the impact on the development and progression of infectious diseases.

\section{Parasitic infections}

Leishmaniases comprise a wide range of diseases caused by the infection with the protozoan parasite Leishmania transmitted by the bite of infected female phlebotomine sandflies. Infection clinical presentation may be asymptomatic or may manifest as cutaneous or muco-cutaneous disease, which if left untreated may result in disfiguring scars; or the visceral form that may be lethal if untreated. The lack of a vaccine against human leishmaniasis and the diverse response to treatment make this disease a significant worldwide health problem. Several studies suggest a potential contribution of purinergic nucleotidases in Leishmania immune responses [45]. Indeed, Leishmania parasites augment ectonucleotidases activity to increase ADO production and consequently establish a chronic infection through purinergic immunoregulatory mechanisms [46]. Patients with visceral leishmaniasis (VL) present increased levels of ADA and ADO [47]. Increased ADO levels were further confirmed and associated with disease's pathogenicity, diminishing with the successful treatment. Moreover, the frequency of CD73 + CD39+double-positive cells is augmented in VL active disease compared with treated VL patients and healthy controls[48]. Additionally, circulating monocytes exhibit upregulated levels of ADORA2b receptor, which shows direct association with parasite load. ADO signaling in L. donovani-infected monocytes inhibits IL-10 production and nitric oxide (NO) release, promoting immune downmodulation and parasite survival [49]. Besides, bone marrow (BM) from VL patients shows increased ADA levels compared to the non-infected BM, which inversely correlated with the local parasite load [50]. Recently, it was demonstrated that murine macrophages release ATP and increase CD39 and CD73 expression upon in vitro L. donovani infection. Thus, the resulting extracellular ADO promotes an antiinflammatory microenvironment crucial for parasite persistence through ADORA2a and ADORA2b signaling [51]. On the other hand, L. infantum parasites utilize ADORA2a signaling pathway to successfully colonize the host and promote parasite surveillance. Indeed, ADORA2a-deficient mice present robust Th1 adaptive immune response in infected organs with augmented neutrophil infiltration and decreased Treg cells and IL-10 production. In accordance, infected ADORA2aKO mice show reduced parasite burdens in liver and spleen compared to infected wild-type (WT) mice [52]. Furthermore, after L. amazonensis infection, murine macrophages are significantly more sensitive to extracellular ATP-induced pore opening and show augmented P2X7R expression. ATP treatment inhibits parasite growth in an apoptosis-dependent mechanism [53]. Interestingly, L. amazonensis elimination mediated by P2X7R and LBT4 is dependent on non-canonical NLRP3 inflammasome and IL-1 $\beta$ signaling activation, as well as ROS production [54]. A crosstalk between P2Y2R and P2X7R is evidenced by the fact that both receptors cooperate to trigger a potent protective response against L. amazonensis infection [55]. However, Countinho-Silva and colleagues proposed another protective role for P2X7R since infected P2X7R-deficient mice show increased IFN- $\gamma$ and reduced TGF- $\beta$ production suggesting that an exacerbated pro-inflammatory response could increase the susceptibility to infection. In fact, P2X7R abrogation results in increased L. amazonensis parasite load and lesion size [56]. Altogether, these studies suggest that purinergic signaling plays a critical role in host immune response and parasite interaction; however, the fine balance of those signals would determine the outcome of infectious diseases.

Notably, several reports established a close relationship between the E-NTPDase and ecto-5' -nucleotidase activities to the virulence in different species of Leishmania genus [57]. The virulent parasite L. amazonensis hydrolyzes higher amounts of purinergic nucleotides compared to other species. Addition of ADO at the time of infection results in augmented skin lesion size and parasite load. In the same line, ADORA2b receptor inhibition decreases injury size and parasitism. Thus, ADO immunomodulatory properties contribute to the establishment of Leishmania infections [58]. Previous studies reported that L. amazonensis employs ADORA2b receptor signaling to suppress dendritic cell activation as an evasion mechanism. Blockade of ADORA2b receptor by PSB1115 treatment in vivo reduces lesion size and tissue parasitism, as well as increases IFN- $\gamma$ levels [59].

Toxoplasmosis is caused by the infection with the protozoan parasite Toxoplasma gondii and is one of the most common human zoonoses, infecting about a third of the world's population. The disease is generally benign and often goes unnoticed in immunocompetent individuals; however, the infection also has health-threatening and fatal implications in immunocompromised individuals. In immunodeficiency conditions, reactivation of a latent infection might result in encephalitis, which is potentially fatal if not treated properly. Susceptibility to this infection is determined by the inability of the host immune response to control parasite replication. 
Toxoplasma gondii-infected Wistar rats present increased E-NTPDase and E-ADA activities in circulating lymphocytes at early days post-infection, showing a positive correlation with the number of lymphocytes [60]. Likewise, the infection causes increment in the purine levels in the brain with the exception of inosine, which was diminished due to diminished ADA activity [61]. Treatment of $T$. gondiiinfected Swiss mice with resveratrol, a non-flavonoid polyphenol, decreases ATP and AMP hydrolysis by NTPDase and CD73 and increases ADA activity in the cerebral cortex compared with non-treated infected groups [62]. Nevertheless, several studies assign a protective role to the purinergic ectoenzymes against $T$. gondii infection. CD73 genetic deficiency in mice infected with $T$. gondii increases their susceptibility to acute toxoplasmosis, with augmented neutrophils and $\mathrm{T}$ cell infiltration into the peritoneal cavity and increased levels of pro-inflammatory cytokines. Because of this, the ADO receptor agonist (NECA) treatment protects CD73deficient mice against $T$. gondii-induced immunopathology [63]. In the same line, CD73-dependent ADO production and ADORA2a/2b activation protect the host from developing lethal pathology. Acute T. gondii infection induces the reduction of $\mathrm{CD} 73+$ cells in several infected tissues and increases immune-mediated pathology in the gastrointestinal tract and mucosa [64].

In contrast to the acute infection, during chronic toxoplasmosis CD73-generated ADO has a detrimental role because it is essential for $T$. gondii bradyzoite differentiation and cyst formation in the central nervous system. Indeed, CD73-deficient mice are more resistant to chronic infection and present reduced parasite burden in the brain compared to WT mice [65]. Accordingly, it is of ultimate importance to consider the radical differences between host immune response during the acute or chronic phases of the infection to therapeutically promote parasite eradication. Alternatively, the P2X7R was widely studied as a host mechanism of resistance to infection. P2X7R deficiency in oral T. gondii-infected mice leads to higher susceptibility to cerebral toxoplasmosis, with an increased number of cysts, less inflammatory infiltrates and reduced pro-inflammatory cytokine levels [66]. In this sense, it was demonstrated that $\mathrm{P} 2 \mathrm{X} 7 \mathrm{R}$ activation inhibits T. gondii replication in macrophages by canonical NLRP3 inflammasome activation, which in turn produced IL-1 $\beta$ leading to increased mitochondrial ROS production [67]. These findings are consistent with other reports confirming that P2X7R activation in macrophages mediates the killing of tachyzoites [68, 69]. Furthermore, P2X7R signaling in epithelial cells mediates CCL5 chemokine responses to promote the recruitment of $\mathrm{CD} 11 \mathrm{c}+\mathrm{CD} 103+$ dendritic cell in the intestinal epithelium promoting the initiation of the immune response [70]. Besides, activation of $\mathrm{P} 2 \mathrm{Y}$ receptors in infected macrophages mediated by UTP and UDP induces early egress of tachyzoites and these parasites have reduced infectivity in subsequent infections [71]. The role of purinergic signaling in $T$. gondii infection was recently summarized in [72].

Chagas disease is caused by the infection with the protozoan parasite Trypanosoma cruzi. About 6 million people are estimated to be infected worldwide, mostly in Latin America. Chronic cardiomyopathy represents the most frequent and serious complication of this infectious disease. To date, there is no effective chemotherapy or prophylactic vaccine. Our group has reported that Chagas patients in the indeterminate stage show diminished frequencies of circulating CD39+ and CD73 + lymphocytes and increased plasma ATP levels [73]. In line with this, peripheral monocytes exhibit long-lasting functional phenotypic changes evidenced by increased expression of HIF- $1 \alpha$ (the master regulator of metabolic adaptation to hypoxia), pro-inflammatory cytokines (IL-1 $\beta$, IL-6), and pro-oxidative capacity. Strikingly, Chagas patients show augmented frequency of CD39+ monocytes and increased expression of CD73 per cell compared to healthy donors [74]. Thus, it is plausible that circulating monocytes promote ATP degradation to dampen the inflammatory microenvironment. Besides, leukocytes within cardiac explant from terminal Chagas disease patients exhibit a strong expression of CD73 and HIF- $1 \alpha$, which positively correlates with the myocarditis degree and the local parasite burden (Fig. 2B) [75]. Regarding ATP receptors, the gene and protein expression of P2X7R are unaltered in circulating lymphocytes from patients with indeterminate form of Chagas disease [76].

In experimental models of Chagas disease, infected Swiss mice increase NTPDase and E-ADA activities in circulating lymphocytes and augment E-ADA activity in cardiac homogenates, although a reduction on tissue CD73 activity is found in the acute phase compared to uninfected controls [77]. Furthermore, E-NTPDase and E-ADA activities are higher in splenic lymphocytes of acutely $T$. cruzi-infected mice compared to uninfected controls. The prophylactic treatment with avian IgY (polyclonal immunoglobulins against $T$. cruzi parasite) prevents these alterations in ectoenzyme activities and reduces the parasitemia [78]. Similarly, our group has previously reported that transient pharmacological specific inhibition of CD73 in the murine acute phase of infection enhances the microbicidal M1-like macrophage subset, promotes a pro-inflammatory environment and diminishes cardiac parasite load. Likewise, $T$. cruzi infection of CD73KO mice leads to an enhanced cardiac antimicrobial immune response as it augments the frequency of M1-like macrophages with enhanced production of IL-12 and the microbicidal metabolite NO. Additionally, C73-deficient mice presented increased CD8 + T cell effector functions which induces protection as observed by the reduced cardiac parasite burden compared to their WT counterpart (Fig. 2A) [79]. Thus, CD73 inhibition ameliorates the 


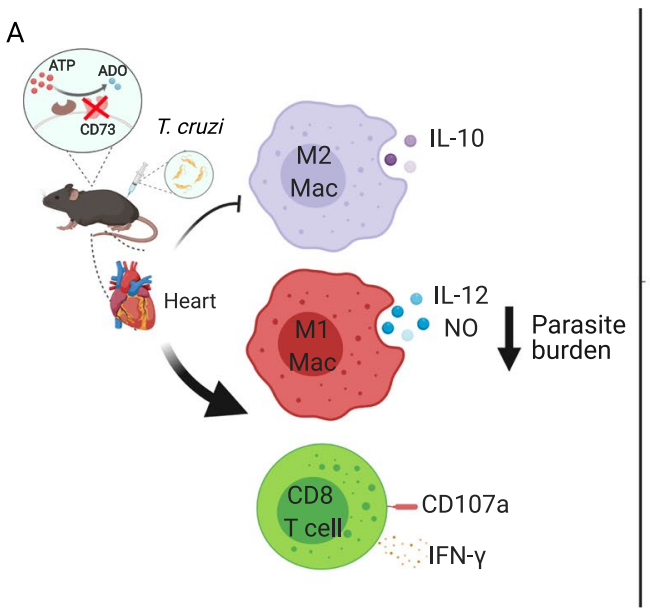

Fig. 2 Ectonucleotidases regulation of immune response against Trypanosoma cruzi infection. T. cruzi infection manipulates the expression of purinergic enzymes. (A) T. cruzi-infected CD73KO mice have an enhanced cardiac microbicidal immune response. CD73 abrogation diminishes IL-10 production of M2-like macrophages (M2 Mac) and augments the effector response (IL-12 and nitric oxide; NO) of M1-like macrophages (M1 Mac). CD73KO mice present augmented cytotoxic and pro-inflammatory (CD107a and IFN-

outcome of chronic Chagas cardiomyopathy as it diminishes biochemical myocardial-specific injury marker (CK-MB) and improves the electrocardiographic characteristics [80].

It must be taken into account that parasites have catabolic ATP machinery which can affect the host's immune response favoring their virulence and persistence. In fact, different strains of T. cruzi parasites exhibit distinct levels of ATPDase hydrolytic activities. After treatment with ATPDase inhibitors, a marked reduction of trypomastigotes infectivity is observed in in vitro culture. Likewise, infection with Ecto-NTPDase-inhibited trypomastigotes leads to lower levels of parasitemia and higher mouse survival than infection with non-inhibited parasites [81]. Analogue products of purines (3'deoxyadenosine and deoxycoformycin) were used as antiparasitic treatments, and the observed therapeutic effect is due to an inability of trypanosomes to engage in new purine synthesis [82]. Hence, more studies are needed to elucidate whether it is possible to promote anti-T. cruzi immune response and at the same time inhibit parasite virulence factors.

Malaria is caused by five species of eukaryotic Plasmodium parasites transmitted by the bite of Anopheles spp. mosquitoes to humans. Malaria remains one of the most severe infectious diseases; it is responsible for hundreds of thousands of deaths predominantly among children in Africa. Purine signaling modulation seems to have relevant importance for Plasmodium parasites infectivity and malaria blood stage. Several studies have shown E-NTPDase to be involved in the infectivity of $P$. falciparum due to its

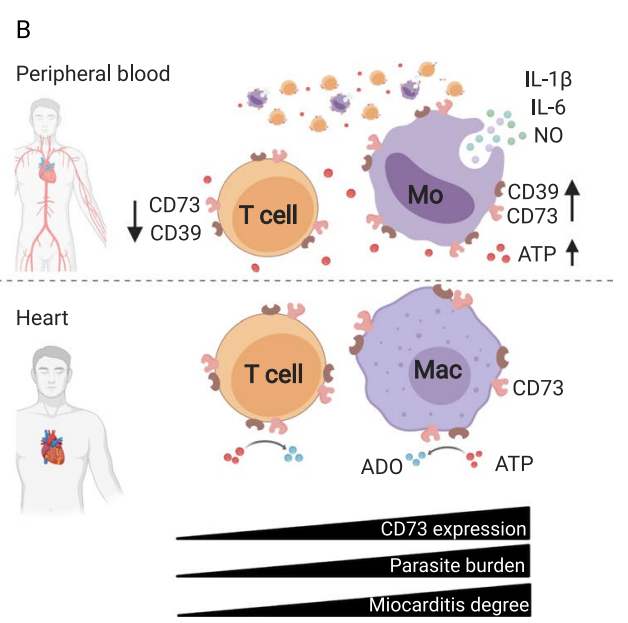

r) $\mathrm{CD} 8+\mathrm{T}$ cell response, which induces protection as observed by the reduced parasite burden. (B) Patients with chronic asymptomatic Chagas disease show diminished ectonucleotidases expression (CD73 and CD39) in circulating lymphocytes and increased expression in monocytes. In human cardiac tissue, the augmented expression of CD73 positively correlates with the myocarditis severity and the cardiac parasite burden

relevance for parasite life cycle [83]. Inhibition of purinergic signaling by apyrase inhibitors impairs $P$. falciparum replication and reduces red blood cells (RBC) infection [84]. Indeed, mammalian RBCs express ADORA2b and several $\mathrm{P} 2 \mathrm{Y}$ and $\mathrm{P} 2 \mathrm{X}$ receptors on their surface [85]. In experimental cerebral malaria the expression of several P2X and P2Y receptors is altered after $P$. berghei infection [86]. However, to date little is known about purinergic modulation of malaria-specific immune response. Recent studies suggest that the expression of P2X7R in CD4 $+\mathrm{T}$ cells could be critical for Th1 profile development and IL- 2 and IFN- $\gamma$ production during chronic $P$. chabaudi infection, while increasing the $\mathrm{T}$ follicular helper (Tfh) cell population [87]. P2X7R-deficient mice present increased susceptibility to infection, which is associated with impaired Th1 response. Furthermore, infected children with severe malaria show augmented expression of CTLA-4 and PD-1, while children with uncomplicated malaria show increased CD39+ and Granzyme B + CD $4+\mathrm{T}$ cells, indicating that distinctive regulatory mechanisms are triggered and may influence the clinical outcome of acute malaria [88].

Helminthiases are heterogeneous diseases caused by helminths, which are large multicellular pathogens that affect one-quarter of the human population. On the other hand, helminths are mainly controlled and eradicated by a canonical type 2 immune response [89]. The mammalian immune system needs to initiate rapid and effective anti-helminth mechanisms while simultaneously organizing the repair of inflicted mechanical damage to re-establish homeostasis 
and prevent immunopathology. Although two antiparasitic drugs (moxidectin in 2018 and triclabendazole in 2019) have been recently approved by the FDA to treat helminthiases, these infectious diseases continue to be an important health problem, mainly among the poorest population[90]. Regarding purinergic modulation of anti-helminth type 2 immune responses, $\mathrm{ADO}$ is reported to play a protective role. Patel and colleagues reported that ADO signaling through ADORA2a induces Heligmosomoides polygyrus worm expulsion and a robust associated development of type-2 immune response. Mice genetically deficient in ADORA2a receptor exhibit increased $H$. polygyrus parasite load, decreased M2 macrophages and eosinophils recruitment and reduced IL- 4 and IL-13 production against the tissue-dwelling parasites [91]. On the other hand, CD39 ectoenzyme activity has a controversial role in filariasis, a chronic helminth infection. Patients infected with filarial nematodes, such as Mansonella ozzardi, exhibit augmented frequency of circulating CD39+CD4+T cells compared to control donors, which correlates with the filarial parasite load. Infected patients also present decreased plasma TNF, IL-8 and IL-6 levels than their non-infected counterparts. Besides, CD39 inhibition decreases lymphocyte proliferation in vitro and pro-inflammatory cytokine response [92]. Moreover, during murine Schistosoma mansoni infection, mesenteric endothelial cells increase the expression of NTPDases 2 and 3 favoring local ATP hydrolysis and mononuclear cell adhesion via P2Y1R. This mechanism may contribute to mesenteric inflammation and infection morbidity [93]. Some authors propose the purinergic signaling as a potential target to reduce schistosomiasis morbidity [94]. In fascioliasis, an infectious disease caused by Fasciola hepatica, the purinergic pathway modulation depends on the phase of infection. In the acute phase, a decrease in NTPDase activity in serum and an increase in the ectoenzyme activity in the liver are observed. In contrast, after the establishment of chronic infection, an increase in NTPDase and 5'nucleotidase activities is found in both periods of infection. The modulation of purinergic environment may generate high ADO levels, which promotes host protection due to tissue injury caused by chronic infection [95]. Altogether, these findings reveal the direct involvement of purinergic pathways in immune response modulation in several parasitic infections. Given the current unmet medical need for novel pharmacological approaches, further studies are needed to deepen the knowledge in the molecular mechanisms and provide supporting evidence to evaluate purinergic target candidates for the treatment of neglected parasitic disease.

\section{Bacterial infections}

Tuberculosis (TB) is one of the most widely spread infectious disease and one of the major causes of mortality, since about two million people die annually because of this disease. It is caused by Mycobacterium tuberculosis and, less frequently, M. bovis. The lung is the portal of M. tuberculosis, as transmission occurs upon inhalation of aerosolized bacilli coughed from the lungs of infected individuals, so TB is primarily a pulmonary disease. However, it has many other manifestations, affecting bones, the central nervous system, among many other systems. The immune response against TB infection has been reported to be modulated by the purinergic pathway. TB patients present an increased Treg cell population $\left(\mathrm{CD} 4+\mathrm{CD} 25^{\text {high }} \mathrm{CD} 39+\right)$ with regulatory properties. Depletion of CD39+ Treg cells significantly augments anti-TB $\mathrm{T}$ cell responses in vitro [96]. Likewise, CD39 mediates suppressive functions in CD8 + Treg cells in patients with active TB [97]. These reports suggest that CD39 plays an important role in the immunosuppression exerted by human Treg cell populations, possibly contributing to the balance between immune-mediated suppression and immunopathology in patients with TB. The CD73 ectoenzyme has also been described to modulate the anti-mycobacterial immune response. Indeed, CD73 activity restricts the early influx of neutrophils to the infected lungs without affecting bacterial load and spreading [98].

Purinergic receptors also have a role in determining the outcome of TB. P2X7R signaling in macrophages had a detrimental role in severe TB infection. Intracellular proliferation of high-virulent mycobacteria results in massive macrophage damage, ATP release and activation of P2X7R augment macrophage necrosis and spread the bacilli. Therefore, infected WT mice exhibit wide lung leukocyte infiltration and high mortality, in contrast to infected P2X7RKO mice, which showed moderate leukocyte infiltrates with ameliorated lung pathology [99]. Similarly, P2X7R signaling blockade with the antagonist BBG during experimental advanced pulmonary TB prevents the development of severe form of TB pathology in mice [100]. Additionally, chimeric WT mice with adoptive transfer of P2X7RKO hematopoietic cells show lower lung $M$. bovis bacterial burden and reduced pneumonia compared to WT mice. Lung necrosis and bacterial spreading to the spleen and liver are also diminished, suggesting that P2X7R in hematopoietic cells play a central role in the progression to severe TB [101]. In contrast to the results observed with high-virulence $M$. tuberculosis and M. bovis strains [99, 101], another report showed that P2X7RKO mice infected with less virulent $M$. tuberculosis exhibit augmented bacillary load in the lungs and increased Treg population but decreased B cells compared to WT mice [102]. Additionally, the potentiation of P2X7R augments inflammasome activation, resulting in the limitation of mycobacterial proliferation [103]. Indeed, patients with polymorphism in $1513 \mathrm{C}$ allele from P2X7R gene have increase susceptibility to extrapulmonary TB [104]. Given these results, it is plausible to speculate that immune response downstream P2X7R activation depends 
on the mycobacterial virulence. ATP/P2X7R axis seems to be essential in the inflammasome-dependent IL- $1 \beta$ production and pathogen clearance in vivo in different bacterial infections (Fig. 3) [105, 106]. On the other hand, a critical modulatory function was assigned to the ADORA2a receptor during severe TB. AMP regulates macrophage state through ADORA2a receptor signaling. After ATP stimulation, it was quickly hydrolyzed to AMP, which downregulates inflammatory response and chemokine family genes, as well as strongly upregulates genes related to tissue repair, wound healing and angiogenesis [107]. In the same way, caffeine treatment, an ADORA2a receptor antagonist, enhances accumulation of $\mathrm{CD} 4+\mathrm{T}$ cells with increased IFN- $\gamma$ production in the lungs and promotes mouse survival during severe TB [108].

Streptococcus pneumoniae infection causes different illnesses, such as pneumonia, bacteremia and meningitis. $S$. pneumoniae interferes with the purinergic signaling by the induction of P2Y2R internalization in pulmonary epithelial cells in vitro, suggesting that bacteria may exert purinergicdependent evasion mechanisms to promote infection [109]. Nevertheless, the host creates an adenosinergic microenvironment to be protected from exacerbated inflammation during infection. ADA-inhibited mice exhibit increased resistance to infection and ten-thousand-fold diminished bacterial load in the lungs and undetectable bacteremia. In contrast, CD73 pharmacologic inhibition induces increased susceptibility with higher pulmonary bacterial burden and increased bacteremia compared to mock-treated mice. The mechanism underlying this effect seems to be executed by ADO since it downregulates the neutrophil infiltration and their bactericidal ability, and the absence of these regulatory mechanisms is reported to be detrimental to the host [110]. Confirming this speculation, the authors found that CD73 augments neutrophil bactericidal activity by inhibiting IL-10 production, which is essential for ROS secretion [111]. On the other hand, ADORA1R signaling was reported to inhibit bacterial binding to human lung epithelial cells increasing host resistance to pulmonary infection [112]. Likewise, CD73-dependent ADO production signaling via ADORA2a receptor on B cells promotes isotype switch and regulates antibody response against $S$. pneumoniae infection. Stimulation of ADORA2a receptor with CGS21680 agonist augments IgG3 antibody protection in vaccinated young mice and enhanced survival after challenge [113]. On the other hand, ADORA2bR deficiency promotes extracellular bactericidal activity in neutrophils, enhancing NETs production. Indeed, ADORA2bR-deficient mice show diminished lung bacterial load and improved survival [114].

It has been also well-documented that purinergic signaling modulates immunity against enteropathogenic infections[115]. CD73 is highly expressed in the colonic epithelium, more specifically in the apical surface of intestinal epithelial cells (IECs). CD73 knockdown (KD) in IECs protects against Salmonella colitis as demonstrated by less marked weight loss and decreased colon shortening. CD73KD mice also show reduced bacterial translocation to the lumen and decreased Salmonella load in mesenteric lymph nodes, spleen and liver, suggesting that ADO promotes initial invasion and systemic dissemination [116]. Salmonella infection also induces downregulation of CD39 and CD73 ectoenzymes in CD4 + T cell population. Inhibition

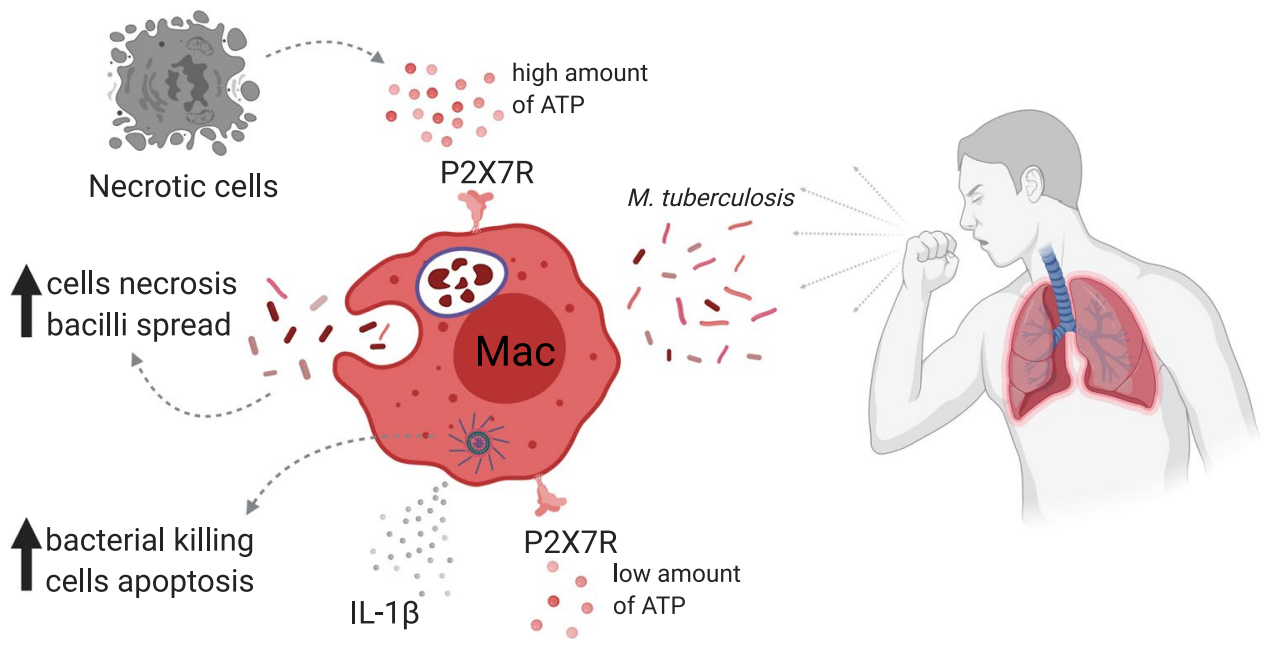

Fig. 3 P2X7R dual function in Mycobacterium tuberculosis infection. P2X7R activation plays a crucial role in control of infectious diseases. ATP-induced P2X7R activation may participate in the control of M. tuberculosis by improving intracellular pathogen killing and triggering the assembly and activation of the inflammasome and the consequent release of pro-inflammatory cytokines, such as IL-1 $\beta$.
However, its role in the host defense against $M$. tuberculosis infection is still controversial, due to its strong pro-inflammatory and cytotoxic activity; it may potentiate tuberculosis progression and the associated tissue damage. High concentrations of ATP can activate the P2X7R and induce the necrosis of infected cells leading to the spread of the bacilli and worsening the disease 
of CD73 enzymatic activity in Salmonella whole cell lysate (WCL)-treated cells increases pro-inflammatory cytokine production, such as IFN- $\gamma$, TNF and IL- $1 \beta$ and inducible nitric oxide synthase (iNOS), leading to a more efficiently elimination of Salmonella bacteria compared to infected WT cells [117]. In addition, CD73 inhibition of Salmonella WCL-treated macrophages enhances the production of NO, pro-inflammatory cytokines IL- $1 \beta$ and TNF. Phagocytosis and intracellular killing are significantly higher in the APCP (CD73 inhibitor)-treated macrophages and in CD73KO peritoneal macrophages than untreated and CD73-competent macrophages [118]. Altogether, these results suggest that inhibiting ADO formation promotes pro-inflammatory and bactericidal functions in macrophage and improves the host's resistance to Salmonella infection. On the other hand, it has been also reported that P2X7R restricts Tfh cell expansion and germinal center reaction in the Peyer's patches in the setting of this infection. Depleting extracellular ATP, via administration of exogenous apyrase, increases the induction of specific $\operatorname{Ig}$ A in response to Salmonella infection or an inactivated oral vaccine providing better protection from secondary infection [119]. Thus, preventing ATP accumulation could also be favorable for the improvement of the immune response against Salmonella infection.

Sepsis is a severe health condition caused by the exacerbated immune response to a microbial systemic infection. Extracellular ATP levels are augmented in the mouse model of polymicrobial sepsis induced by the cecal ligation and puncture (CLP). In this sense, several works have described the protective function of macrophages in septic conditions. ATP signaling in macrophages via P2X4R mediates a stimulatory effect on E. coli bacterial killing through augmented ROS production. P2X4R stimulation improves mouse survival by decreasing bacterial burden, pro-inflammatory cytokines, chemokine levels and spleen, liver and kidney injury in CLP-induced sepsis. As a logical consequence, pharmacological stimulation with ivermectin, a P2X4R agonist, protects the host against bacterial dissemination and mortality in sepsis [120]. Indeed, ADORA2b-deficient macrophages exhibit increased bacteria phagocytosis capacity, while ADORA2bKO mice show decreased peritoneal bacterial load and improved survival in a CLP model of sepsis [121]. Likewise, accumulation of adenosine by expanded CD39 + plasmablast subpopulation impairs macrophage bacterial killing and promotes IL-10 production via ADORA2a signaling in septic mice [122]. Besides, employing this mouse model of sepsis, Haskó and colleagues describe a protective role of $\mathrm{P} 2 \mathrm{X} 7 \mathrm{R}$ in macrophages by diminishing bacterial load and production of pro-inflammatory cytokines and chemokines, as well as improving mouse survival [123].

Purinergic signaling is also essential for TLR4induced mitochondrial ATP synthesis and autocrine signaling, required for monocyte/macrophage activation, inflammasome assembly and IL-1 $\beta$ production[124]. ADP protects mice from $E$. coli-induced peritonitis by enhancing MCP-1-dependent recruitment of macrophages to the infected tissues. Both P2Y12R and P2Y13R deficiency inhibit the ADP-mediated immune response and promotes E. coli persistence in infected mice [125]. In the same way, P2X4R- and P2X7R-deficient mice have enhanced susceptibility to sepsis induced by uropathogenic $E$. coli and are more prone to die from a severe infection compared to WT mice. Higher systemic bacterial burden, plasmatic pro-inflammatory cytokines levels and activated coagulation cascade with increased levels of thrombin-antithrombin complexes are associated with their increased mortality [126]. Similarly, constant intravenous infusion with P2X1R antagonist markedly accelerates development of a septic response to $E$. coli-induced bacteremia. P2X1R antagonisttreated mice died at early times post-infection with high bacteremia and hematuria, substantially elevated plasmatic pro-inflammatory cytokines levels, massive intravascular coagulation and a concomitant reduction in circulating platelets [127]. Conversely, ATP-induced P2XR activation in vitro has a key role in the cytotoxic effects of $\alpha$-hemolysin and leukotoxin A on THP-1 human monocytes. Inhibition of P2X1R, P2X4R or P2X7R significantly reduce THP-1 cytolysis protecting macrophage/monocyte phagocytosis function [128]. In vitro experiments also revealed that ATP signaling via P2X7R inhibits J774 macrophage phagocytosis of bio-particles coated with S. aureus or E. coli. A438079, an antagonist of P2X7R, partially reverts the effect of ATP on bacterial phagocytosis [129].

During Staphylococcus aureus infection, the signaling via P2X7R has been described as favorable for the elimination of the bacterial infection. Human macrophages internalize antimicrobial peptide LL-37 derived from neutrophils via a P2X7R-dependent mechanism, primarily involving a clathrin-dependent endocytosis pathway. P2X7R signaling in macrophages enhances intracellular ROS production and accumulation of lysosomes, which promote intracellular S. aureus elimination [130]. Similarly, P2XR inhibitors interfere with binding and oligomerization of hemolysin A from S. aureus (Hla) with cell membranes. The P2XR antagonists restrict the function of a membrane pore-forming toxin through non-canonical mechanisms. The data suggest the need for a critical revision of the notion that P2XRs are enhancers of membrane pore-forming toxin-dependent hemolysis. The role of ATP release and P2XR signaling in destabilizing the membrane stability and induction of pore formation is still controversial [131]. In line with this, several selective P2X7R antagonists inhibited Clostridium perfringens beta-toxin-induced cytotoxicity in THP-1 cells [132]. Finally, it has been shown that several bacteria exploit the production of ADO to dampen inflammation and support their survival during infection [133]. Summing up, the 
findings described clearly illustrate that different pathogenic bacteria may exert their evasion mechanisms based on the production of purinergic metabolites, promoting an immunosuppressive microenvironment to persist in the host and establish a chronic disease. On the other hand, microbiota also can manage the purinergic system to its favor. Further investigations are needed to completely visualize the role of purinergic signaling in the host-bacteria interplay.

\section{Viral infections}

One of the most serious public health problems globally is HIV type 1 (HIV-1) infection since 38 million people are infected worldwide, and almost two million new infections occur each year. Antiretroviral therapies (ART) have allowed infected people to benefit from a better general state of health by significantly increasing their life expectancy thanks to the sustained suppression of viremia. Nevertheless, infected patients suffer from co-morbidities due to chronic inflammation derived from coinfections and immune dysregulation. Several studies emphasize the role of the purinergic pathway in the sustained inflammation and in different cellular processes of the acquired immunodeficiency syndrome (AIDS), usually associates with HIV-1 infection [134, 135]. HIV-1 infects several immune cells such as CD4 + T cells, myeloid dendritic cells and monocyte macrophages, all populations sharing the expression of CD4 receptor along with the chemokines receptors CCR5 and/or CXCR4. Indeed, untreated infected patients present increasing immunodeficiency with decreasing CD4 $+\mathrm{T}$ cell counts and a reversed $\mathrm{CD} 4+/ \mathrm{CD} 8+\mathrm{T}$ cells ratio.

Although it is not fully addressed, ADO contributes to the suppression of CD4 + T cell responses during HIV infection. Numerous authors had reported that the expression of CD39 is upregulated in Treg cells compared to activated CD4 $+\mathrm{T}$ cells in HIV + patients. Regulatory functions of Treg cells are diminished by blocking with anti-CD39 antibody in a coculture of Treg and CD8 + T cells. Furthermore, it was also shown that the expansion of CD39+ Treg cells inversely correlates with CD4 $+\mathrm{T}$ cells counts in treated patients [136]. In line with this, IL-2 production by activated CD4 + T cells is suppressed by CD39+ Treg cells via ADO/cAMP enzymatic pathway. Increased expression of ADORA2a receptor and intracellular cAMP levels in CD4 + T cells of HIVinfected patients diminishes IL-2 production and inhibits $\mathrm{T}$ cell proliferation [137]. Treg cells serve as viral reservoirs during chronic infection. Patients with advanced AIDS exhibit increased CD39 expression, and the CD39 + naïve Treg frequency directly correlates with HIV DNA levels [138]. Altogether, these findings suggest that CD39 pathway in Treg cells may be playing a deleterious role in the progression of HIV infection by suppressing CD4+ and
$\mathrm{CD} 8+\mathrm{T}$ cell responses and contributing to chronic inflammation and $\mathrm{T}$ cell dysfunction. Another mechanism that may be responsible for the AIDS pathogenesis is the significantly augmented frequency of CD39+CD56 $6^{\text {bright }} \mathrm{NK}$ cells, observed in untreated HIV patients. This NK cell subpopulation is associated with an increased viral load, lower CD4 + T cell count and disease progression. Indeed, the authors propose CD39 as a marker of a regulatory NK subpopulation, since it exhibits increased AhR expression and IL-10 production [139]. Moreover, CD73 is also involved in the regulation of $\mathrm{T}$ cell activation. Contrasting to CD39+ Treg subset, CD73 + cells do not express FoxP3 and $\mathrm{CD} 25$ at high levels; thus, $\mathrm{CD} 73+\mathrm{CD} 4+\mathrm{T}$ cells represent a phenotypically and functionally different subpopulation [140]. CD73 + CD4 + T cell subset is preferentially depleted in HIV + patients compared to healthy controls, regardless of viral load and treatment. This subset depletion suggests the existence of an ADO-diminished microenvironment that may be unable to prevent persistent immune activation. Supporting this idea, an inverse correlation was shown between the $\mathrm{CD} 73+\mathrm{CD} 4+\mathrm{T}$ cell count and $\mathrm{T}$ cell activation, as well as plasma $C$ reactive protein levels [141]. Additionally, HIV-infected patients show diminished expression of CD73 on CD $8+\mathrm{T}$ cells, which is correlated with disease progression and partially reverts after effective ART [142]. Besides, CD73 is involved in the expansion of HIV-specific CD8 + T cells, whereas CD73 expression is higher in memory CD $8+\mathrm{T}$ cell subset. The frequency of CD73 + CD $8+\mathrm{T}$ cells is inversely associated with cell activation and plasma viral load. Interestingly, HIV controllers express high levels of CD73 [143]. Besides, untreated chronic patients present lower frequency of CD39+CD73 + B cells compared to ART-treated patients and healthy controls. Downregulation of CD73 on B cells is associated with augmented expression Ki67 + and PD-1. In addition, CD73 loss also correlates with low CD4 + T cell counts, higher expression of markers of cellular proliferation and exhaustion, such as Ki-67 and PD-1, and decreased in vitro AMP catabolic activity and IgG switch ability dysregulation [144]. All these results in HIV + patients are depicted in Fig. 4.

Another component of the purinergic system that is associated with increased immune activation is ADA due to its potential to reverse immunosuppression driven by extracellular ADO. It has been shown that in both healthy and HIV-infected individuals, ADA is associated with increased expression of costimulatory molecules CD80, CD83, CD86 and $\mathrm{CD} 40$, promoting the maturation of DCs regardless of its enzymatic activity as shown after desalting and treatment with $\mathrm{HgCl}_{2}$. ADA treatment enhances DCs immunogenicity and promotes their capacity to stimulate allogenic T cell subpopulations to proliferate [145]. In line with this, it has also been shown that in autologous co-cultures of $T$ cells with HIV-1 peptide-pulsed DCs, the addition of ADA leads to a 


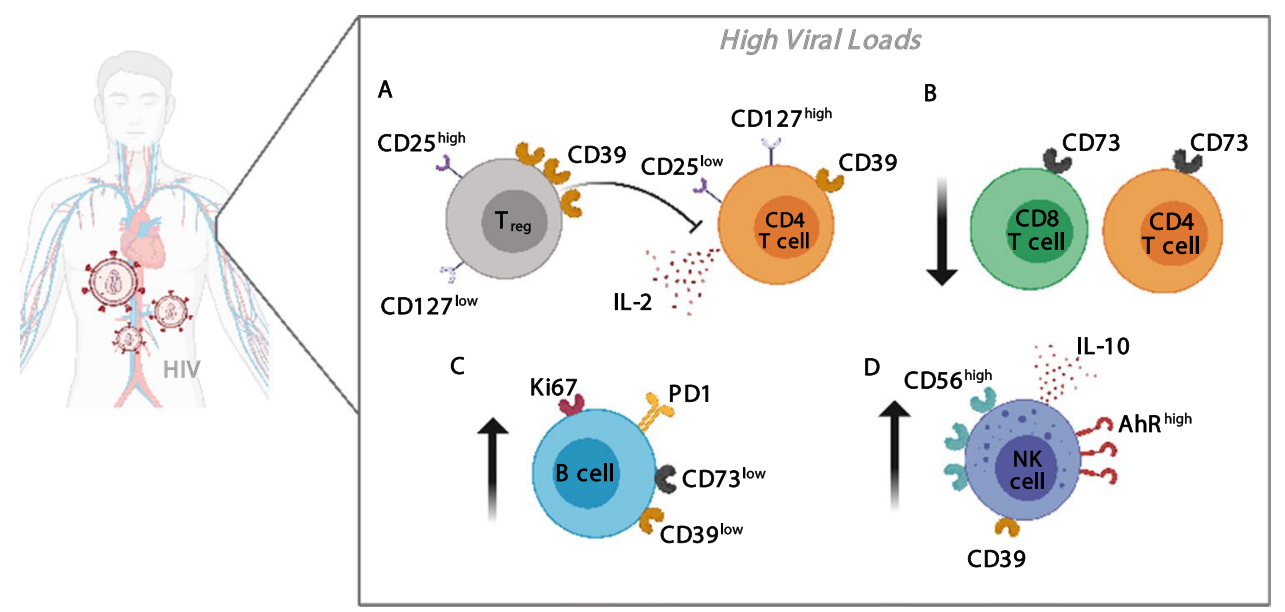

Fig. 4 Purinergic dysregulation in untreated HIV + patients with high viral loads. (A) CD39+ Tregs suppress in vitro IL-2 production by activated $\mathrm{CD} 4+\mathrm{T}$ cells via adenosine/cAMP enzymatic pathway. (B) CD4+ and CD8+ T cells subsets expressing CD73 ectoenzyme are preferentially depleted in HIV + patients compared to healthy controls, regardless of viral load and treatment. (C) Untreated chronic patients present diminished frequency of $\mathrm{CD} 39+\mathrm{CD} 73+\mathrm{B}$ cells.

reduction in Treg frequency and to a significant enhancement of HIV-1-specific effector CD4 + T cells in a dose-dependent manner. At the same time, ADA addition increases the secretion of Th1 inflammatory cytokines and proliferation of CD8 + T cells, demonstrating that ADA treatment could improve the immune subpopulations involved in the control of HIV-1 infection [146]. These results are in agreement with previous reports showing that the addition of extracellular ATP to the co-cultures also inhibits the propagation of HIV-1 from the immature DCs to autologous CD4 + T lymphocytes [147]. ADA-1 modulates the program of circulating and germinal center Tfh cells, enhancing their function. This mechanism promotes effective collaboration between $\mathrm{T}$ and B cells and the generation of antibodies, by influencing the production of IL6/IL-2 and controlling the expression of CD26 and the ADORA signaling. The authors suggest that ADA represents a potential target for the development of Tfh-targeted vaccine strategy [148].

It should be noted that purinergic signaling has been associated with both a protective and pathological role in different viral infections. The role of adenosine pathway signaling in HIV infection has been addressed in[149]. For example, HIV infection of CD4 + T cell induces Panx1 hemichannels opening, required for effective HIV replication in CD4 + T lymphocytes [150]. Furthermore, ATP activates P2Y2R and induces activation tyrosine kinase 2 and transient depolarization of the plasma membrane, which stimulates fusion between the envelope protein and CD4-containing membranes [151]. On the other hand, P2X1R inhibition has been reported to block HIV-1 entry and replication within target cells [152]. Inhibition of P2X1R, P2X7R and P2Y1
In fact, the downregulation of CD73 expression on B cells is associated with augmented cellular proliferation $(\mathrm{Ki} 67+)$ and exhaustion phenotype $(\mathrm{PD}-1+)$. (D) CD39+CD56 $6^{\text {bright }} \mathrm{NK}$ cell subset presents increased AhR expression and IL-10 production and is associated with lower CD4+ T cell counts, higher viral loads and disease progression.

significantly reduces viral replication within human macrophages, whereas P2X1R antagonists block viral entry to the cell. The data also indicate that binding gp120 protein results in the rapid ATP release from macrophages and allows autocrine P2R activation, facilitating HIV infection [153]. In the same way, the ecto-ATPase activity increases in in vitro HIV-1-infected human macrophages and its blockade prevents HIV-1 replication [154]. In fact, it has been proven that P2X1R and P2X7R selective antagonists abrogate both HIV-1 infection and the subsequent inflammation. The purinergic P2X1R and P2X7R antagonists inhibit HIV-1 infection, but only P2X1R antagonists downregulate IL-1 $\beta$ and IL-10 production in ex vivo infection of human tonsil [155]. It has been reported that P2X1R antagonist (NF279) inhibits the fusion with the HIV-1 cell membrane by blocking the virus binding and entrance via CXCR 4 and CCR51 [156]. Moreover, blockade of P2XR signaling inhibits HIV-1 membrane fusion [157].

Extracellular ATP is capable of reducing the replication of DNA and RNA viruses through activation of P2X7R, enhancing the production and release of IFN- $\beta$, which is crucial in promoting antiviral immunity [158]. This is also an essential antiviral mechanism against respiratory viruses. Adenovirus and Influenza viruses increase ATP and ADO levels in the respiratory tract. The induction of purinergic P2X7R signaling plays a key role in generating a robust inflammatory response capable of controlling these infections. If the infection persists, a systemic inflammatory response can be triggered, which is associated with higher mortality. Disruption of the ATP/P2X7R interaction avoids symptoms of acute respiratory distress syndrome (ARDS) 
associated with less infiltration of neutrophils and macrophages and lower levels of pro-inflammatory cytokines, associated with an enhanced survival of mice after infection with Adenovirus [159] or Influenza virus [160]. In turn, a marked increase in morbidity and mortality is observed in P2Y2R-deficient mice in response to lung infection with the human respiratory syncytial virus. The lower survival of the P2Y2KO mice could be associated with the defective infiltration and response of Th1 cells and higher viral titers, evidencing the protective role of $\mathrm{P} 2 \mathrm{Y} 2$ receptor in lung infections [161]. On the other hand, ADORA1R activation significantly contributes to the generation ARDS. Nevertheless, the activity of CD73 is not required to generate ARDS [162]; rather, ADO generation is due to the enzymatic action of tissue non-specific alkaline phosphatase, an enzyme present in the lung parenchyma with low affinity but high capacity to metabolize ATP/AMP in a non-specific way [163].

In December 2019, the new ARDS-related to Coronavirus 2 (SARS-CoV-2) infection that causes COVID-19 disease was reported for the first time in China. As already reported, severe cases are associated with hyper-activation of the immune system and an excessive release of cytokines called cytokines release syndrome (CRS). So far, Ahmadi and colleagues showed that circulating cytotoxic cells (CD8 + T cells, NK cells and NKT cells) express lower levels of CD73 ectoenzyme in COVID-19 patients compared to healthy donors. Furthermore, CD73 + and CD73- subpopulations of CD8 $+\mathrm{T}$ cells and NKT cells with different functionality are observed in COVID-19 patients. CD8 + T cells and NKT cells lacking CD73 exhibit increased cytotoxic effector capacity compared to their counterpart CD73 + [164]. P2X7R hyperactivation has been reported in COVID-19 as a key driver of inflammation and NLRP3 inflammasome activation $[165,166]$, potentially driving central nervous system diseases [165, 167]

Purinergic pathway also has been studied in endemic mosquito-borne viral diseases, such as dengue virus (DENV) infection. This represents the most common arboviral infection in humans and can generate a wide spectrum of clinical manifestations. In severe cases, higher mortality is associated with hyper-activation of the immune system. Through the addition of specific P2X7R inhibitors, several authors demonstrated that $\mathrm{P} 2 \mathrm{X} 7 \mathrm{R}$ signaling generates an increase in antiviral responses, either by augmenting NO and cytokine production in human monocytes [168] or by improving human $\mathrm{T}$ cell function, which provide an early source of IFN- $\gamma$ and killing DENV-infected cells [169]. Dengue hemorrhagic fever is a systemic endothelial dysfunction resulting from the prolonged and exacerbated immune response. Many proteins and signaling pathways are involved in maintaining the integrity of the endothelial barrier, including the CD73/ADO axis. Probably, the endothelial infection with DENV decreases expression of CD73 and this could be associated with a recovery of endothelial barrier function [170].

Viral infections are the major causes of acute and chronic liver diseases such as hepatitis. Hepatotropic virus, such as hepatitis B virus (HBV) and hepatitis delta virus (HDV), requires the activity of $\mathrm{P} 2 \mathrm{XR}$ to infect primary human hepatocytes [171]. In chronic hepatitis C virus (HCV)-infected patients, the expression of P2X1R, P2X4R and P2X7R in peripheral blood mononuclear cells increases compared to control patients. However, it remains to be elucidated whether the expression of purinergic receptors is associated with an antiviral immunity or participates in the pathophysiology of the disease [172, 173]. Furthermore, in patients that develop hepatocellular carcinoma (HCC) induced by a HCV infection, the $\mathrm{P} 2 \mathrm{X} 4 \mathrm{R}$ expression is increased compared to patients with HCC from non-viral causes [174]. Regarding the ectoenzymes, recently a population of CD39+ Treg cells was identified to be associated with potent immunosuppressive activity and the progression of viral infections. Tang and colleagues showed that the proportion of circulating CD39+FoxP3 + Treg cells correlates positively with HBV viremia levels and, conversely, negatively correlates with markers of liver damage [175].

A prominent role of the purinergic system in intestinal function was demonstrated under physiological and pathological conditions. ADO plays a central role in intestinal functions, by modulating the interaction between enteric nervous system (ENS), smooth muscle and epithelial barrier function. Viral-induced ENS neurodysfunction is associated with a markedly altered ADO metabolism, with a spatial and functional reorganization of all ADORA receptors and an increased expression of ADA and CD73 ectoenzyme in the gut [176]. On the other hand, the treatment of different human cell lines with imiquimod, an antagonist of the ADORA1 receptor, suppresses the replication of HSV-1 [177]. Within the family of herpes viruses, the human cytomegalovirus (CMV) is a $\beta$-herpes virus that infects a large proportion of the population worldwide. Unlike what happens in immunocompetent people, it can cause severe diseases in immunosuppressed patients. In vitro studies show that several components of the purinergic signaling system play critical roles within CMV-infected cells. CMV infection induces P2Y2R and P2X5R expression in human fibroblasts. Whereas P2Y2R enhances CMV performance due to its importance for efficient virus gene expression, DNA synthesis and production of infectious progeny, the P2X5R reduces CMV production [178]. On the other hand, the purinergic system may be involved in the carcinogenesis of different chronic viral infections, such as Epstein-Barr virus (EBV)-associated and human papillomavirus (HPV)related carcinomas $[179,180]$. 


\section{Conclusions and therapeutic perspectives}

For several decades, the purinergic system has been extensively studied as possible therapeutic target for inflammatory, autoimmune and oncological diseases [181-186]. Inflammation drives the expression of purinergic components and subsequent, activation of purinergic signaling to prevent tissue collateral damage. After infection, extracellular ATP supports the establishment of a set point of various signaling pathways and affects the responses of immune cells. Therapies targeting increased ATP and P2 receptor signaling may be fundamental in controlling the collateral injury and maintaining healthy tissues for the survival of the host in the acute phase of infection. In particular, ATP-P2X7R pathway inhibition may be potentially effective for therapeutic development [44]. ATP catabolism to ADO remarkably increases as a result of the activities of extracellular ecto-apyrases, ecto-ATPases and ectonucleotidases. Rapid uptake and metabolism of ADO maintains its low levels in healthy and unstressed cells or tissues, but during inflammatory conditions this equilibrium breaks down and extracellular ADO level rises substantially. The imbalance of the purinergic microenvironment and its signaling mechanism can trigger immune exacerbation or suppression. Resulting purinergic microenvironment and receptor signaling certainly have a fundamental role as mediators of host immune response and pathogen interaction. Indeed, adenosinergic pathway inhibitors may reinvigorate the immune cell effector functions and improve immune response fitness [187]. Better understanding of the effect of ADO on both host innate and adaptive immune system function in chronic infectious diseases is required to avoid the persistence of the microbe and the progression of the disease [188].

Ectonucleotidases from the microorganisms are major tools to escape from innate and adaptive immunity and should be taken into account as potential targets for new therapeutic approaches, and also, vaccines development $[189,190]$. In some cases, the host's own organism generates an anti-inflammatory microenvironment to prevent vital organs damage and promote survival, thus allowing the microorganism to replicate without having to hide or fight a robust immune response against it. The persistence of numerous microorganisms is improved by their ability to modulate the release of nucleotides and nucleosides and signal host parenchymal and immune cells. Depletion of extracellular nucleotides or pharmacological inhibition of purinergic receptors during certain infections may represent effective strategies to prevent infectious disease. Further investigations will precisely define the molecular actors of these processes and hence might identify a series of novel druggable targets for the treatment of microbial infections.
Acknowledgements MPA is member of the scientific career from the Consejo Nacional de Investigaciones Científicas y Técnicas de la República Argentina (CONICET). NE and GB thank CONICET for the fellowships. YLMM thanks fellowship granted from ANPCyT-FONCyT. Figures were created with BioRender (https://biorender.com).

Authors' Contributions NE developed the concept and performed the bibliographic search. NE, GB, YLMM and MPA wrote the manuscript. NE, GB, YLMM and MPA were responsible for figures design. NE, GB, and YLMM and MPA carefully revised the manuscript.

Funding This work was supported by Secretaría de Ciencia y Tecnología, Universidad Nacional de Córdoba (113/17), Agencia Nacional de Promoción Científica y Tecnológica (ANPCyT) Fondo para la Investigación Científica y Tecnológica (PICT2015-1130 and PICT20171218), Consejo Nacional de Investigaciones Científicas y Técnicas (CONICET) (PIP11220120100620) and Ministerio de Ciencia y Tecnología, Gobierno de la Provincia de Córdoba (114/18).

Availability of data and material/Code availability Not applicable.

\section{Declarations}

Conflicts of interest The authors declare that there is no conflict of interest.

Ethics approval Not applicable.

Consent to participate Not applicable.

Consent for publication Not applicable.

\section{References}

1. Villani AC, Sarkizova S, Hacohen N (2018) Systems Immunology: Learning the Rules of the Immune System. Annu Rev Immunol 36:813-842. https://doi.org/10.1146/annurev-immun ol-042617-053035

2. Cekic C, Linden J (2016) Purinergic regulation of the immune system. Nat Rev Immunol 16(3):177-192. https://doi.org/10. 1038/nri.2016.4

3. Di Virgilio F, Vuerich M (2015) Purinergic signaling in the immune system. Auton Neurosci 191:117-123. https://doi.org/ 10.1016/j.autneu.2015.04.011

4. Burnstock G, Boeynaems JM (2014) Purinergic signalling and immune cells. Purinergic Signal 10(4):529-564. https://doi.org/ $10.1007 / \mathrm{s} 11302-014-9427-2$

5. Yegutkin GG (2008) Nucleotide- and nucleoside-converting ectoenzymes: Important modulators of purinergic signalling cascade. Biochem Biophys Acta 1783(5):673-694. https://doi. org/10.1016/j.bbamcr.2008.01.024

6. Bodin P, Burnstock G (2001) Purinergic signalling: ATP release. Neurochem Res 26(8-9):959-969. https://doi.org/10.1023/a: 1012388618693

7. Burnstock G (2018) Purine and purinergic receptors. Brain Neurosci Adv 2:2398212818817494. https://doi.org/10.1177/23982 12818817494

8. Corriden R, Insel PA (2010) Basal release of ATP: an autocrineparacrine mechanism for cell regulation. Sci Signal 3(104):re1. https://doi.org/10.1126/scisignal.3104re1 
9. Junger WG (2011) Immune cell regulation by autocrine purinergic signalling. Nat Rev Immunol 11(3):201-212. https://doi.org/ 10.1038/nri2938

10. Faas MM, Saez T, de Vos P (2017) Extracellular ATP and adenosine: The Yin and Yang in immune responses? Mol Aspects Med 55:9-19. https://doi.org/10.1016/j.mam.2017.01.002

11. Antonioli L, Pacher P, Vizi ES, Hasko G (2013) CD39 and CD73 in immunity and inflammation. Trends Mol Med 19(6):355-367. https://doi.org/10.1016/j.molmed.2013.03.005

12. Hasko G, Cronstein BN (2004) Adenosine: an endogenous regulator of innate immunity. Trends Immunol 25(1):33-39. https:// doi.org/10.1016/j.it.2003.11.003

13. Soderback U, Sollevi A, Fredholm BB (1987) The disappearance of adenosine from blood and platelet suspension in relation to the platelet cyclic AMP content. Acta Physiol Scand 129(2):189194. https://doi.org/10.1111/j.1748-1716.1987.tb08058.x

14. Idzko M, Ferrari D, Eltzschig HK (2014) Nucleotide signalling during inflammation. Nature 509(7500):310-317. https://doi.org/ 10.1038/nature13085

15. Chen Y, Corriden R, Inoue Y, Yip L, Hashiguchi N, Zinkernagel A, Nizet V, Insel PA, Junger WG (2006) ATP release guides neutrophil chemotaxis via $\mathrm{P} 2 \mathrm{Y} 2$ and $\mathrm{A} 3$ receptors. Science 314(5806):1792-1795. https://doi.org/10.1126/science.1132559

16. Junger WG (2008) Purinergic regulation of neutrophil chemotaxis. Cell Mol Life Sci 65(16):2528-2540. https://doi.org/10. 1007/s00018-008-8095-1

17. Wang X, Chen D (2018) Purinergic Regulation of Neutrophil Function. Front Immunol 9:399. https://doi.org/10.3389/fimmu. 2018.00399

18. Elliott MR, Chekeni FB, Trampont PC, Lazarowski ER, Kadl A, Walk SF, Park D, Woodson RI, Ostankovich M, Sharma P, Lysiak JJ, Harden TK, Leitinger N, Ravichandran KS (2009) Nucleotides released by apoptotic cells act as a find-me signal to promote phagocytic clearance. Nature 461(7261):282-286. https://doi.org/10.1038/nature08296

19. Regateiro FS, Cobbold SP, Waldmann H (2013) CD73 and adenosine generation in the creation of regulatory microenvironments. Clin Exp Immunol 171(1):1-7. https://doi.org/10.1111/j.13652249.2012.04623.x

20. Dwyer KM, Deaglio S, Gao W, Friedman D, Strom TB, Robson SC (2007) CD39 and control of cellular immune responses. Purinergic Signal 3(1-2):171-180. https://doi.org/10.1007/ s11302-006-9050-y

21. Desai BN, Leitinger N (2014) Purinergic and calcium signaling in macrophage function and plasticity. Front Immunol 5:580. https://doi.org/10.3389/fimmu.2014.00580

22. Hasko G, Pacher P, Deitch EA, Vizi ES (2007) Shaping of monocyte and macrophage function by adenosine receptors. Pharmacol Ther 113(2):264-275. https://doi.org/10.1016/j.pharmthera. 2006.08.003

23. Hamidzadeh K, Mosser DM (2016) Purinergic Signaling to Terminate TLR Responses in Macrophages. Front Immunol 7:74. https://doi.org/10.3389/fimmu.2016.00074

24. Cohen HB, Briggs KT, Marino JP, Ravid K, Robson SC, Mosser DM (2013) TLR stimulation initiates a CD39-based autoregulatory mechanism that limits macrophage inflammatory responses. Blood 122(11):1935-1945. https://doi.org/10.1182/ blood-2013-04-496216

25. Csoka B, Selmeczy Z, Koscso B, Nemeth ZH, Pacher P, Murray PJ, Kepka-Lenhart D, Morris SM Jr, Gause WC, Leibovich SJ, Hasko G (2012) Adenosine promotes alternative macrophage activation via A2A and A2B receptors. FASEB J 26(1):376-386. https://doi.org/10.1096/fj.11-190934

26. Barbera-Cremades M, Baroja-Mazo A, Pelegrin P (2016) Purinergic signaling during macrophage differentiation results in
M2 alternative activated macrophages. J Leukoc Biol 99(2):289_ 299. https://doi.org/10.1189/jlb.1A0514-267RR

27. Hasko G, Pacher P (2012) Regulation of macrophage function by adenosine. Arterioscler Thromb Vasc Biol 32(4):865-869. https://doi.org/10.1161/ATVBAHA.111.226852

28. Cohen HB, Ward A, Hamidzadeh K, Ravid K, Mosser DM (2015) IFN-gamma Prevents Adenosine Receptor (A2bR) Upregulation To Sustain the Macrophage Activation Response. J Immunol 195(8):3828-3837. https://doi.org/10.4049/jimmunol.1501139

29. Schenk U, Westendorf AM, Radaelli E, Casati A, Ferro M, Fumagalli M, Verderio C, Buer J, Scanziani E, Grassi F (2008) Purinergic control of T cell activation by ATP released through pannexin-1 hemichannels. Sci Signal 1(39):ra6. https://doi.org/ 10.1126/scisignal.1160583

30. Schenk U, Frascoli M, Proietti M, Geffers R, Traggiai E, Buer J, Ricordi C, Westendorf AM, Grassi F (2011) ATP inhibits the generation and function of regulatory $\mathrm{T}$ cells through the activation of purinergic P2X receptors. Sci Signal 4(162):ra12. https:// doi.org/10.1126/scisignal.2001270

31. Borges da Silva H, Beura LK, Wang H, Hanse EA, Gore R, Scott MC, Walsh DA, Block KE, Fonseca R, Yan Y, Hippen KL, Blazar BR, Masopust D, Kelekar A, Vulchanova L, Hogquist KA, Jameson SC (2018) The purinergic receptor P2RX7 directs metabolic fitness of long-lived memory CD8(+) T cells. Nature 559(7713):264-268. https://doi.org/10.1038/s41586-018-0282-0

32. Borges da Silva H, Peng C, Wang H, Wanhainen KM, Ma C, Lopez S, Khoruts A, Zhang N, Jameson SC (2020) Sensing of ATP via the Purinergic Receptor P2RX7 Promotes CD8(+) Trm Cell Generation by Enhancing Their Sensitivity to the Cytokine TGF-beta. Immunity 53(1):158-171 e156. https://doi.org/10. 1016/j.immuni.2020.06.010

33. Lappas CM, Rieger JM, Linden J (2005) A2A adenosine receptor induction inhibits IFN-gamma production in murine CD4+ T cells. J Immunol 174(2):1073-1080. https://doi.org/10.4049/ jimmunol.174.2.1073

34. Zarek PE, Huang CT, Lutz ER, Kowalski J, Horton MR, Linden J, Drake CG, Powell JD (2008) A2A receptor signaling promotes peripheral tolerance by inducing T-cell anergy and the generation of adaptive regulatory T cells. Blood 111(1):251-259. https://doi. org/10.1182/blood-2007-03-081646

35. Ohta A, Sitkovsky M (2014) Extracellular adenosine-mediated modulation of regulatory T cells. Front Immunol 5:304. https:// doi.org/10.3389/fimmu.2014.00304

36. Groth C, Hu X, Weber R, Fleming V, Altevogt P, Utikal J, Umansky V (2019) Immunosuppression mediated by myeloid-derived suppressor cells (MDSCs) during tumour progression. Br J Cancer 120(1):16-25. https://doi.org/10.1038/s41416-018-0333-1

37. Borsellino G, Kleinewietfeld M, Di Mitri D, Sternjak A, Diamantini A, Giometto R, Hopner S, Centonze D, Bernardi G, Dell'Acqua ML, Rossini PM, Battistini L, Rotzschke O, Falk K (2007) Expression of ectonucleotidase CD39 by Foxp3+ Treg cells: hydrolysis of extracellular ATP and immune suppression. Blood 110(4):1225-1232. https://doi.org/10.1182/ blood-2006-12-064527

38. Deaglio S, Dwyer KM, Gao W, Friedman D, Usheva A, Erat A, Chen JF, Enjyoji K, Linden J, Oukka M, Kuchroo VK, Strom TB, Robson SC (2007) Adenosine generation catalyzed by CD39 and CD73 expressed on regulatory T cells mediates immune suppression. J Exp Med 204(6):1257-1265. https://doi.org/10.1084/jem. 20062512

39. Mascanfroni ID, Takenaka MC, Yeste A, Patel B, Wu Y, Kenison JE, Siddiqui S, Basso AS, Otterbein LE, Pardoll DM, Pan F, Priel A, Clish CB, Robson SC, Quintana FJ (2015) Metabolic control of type 1 regulatory T cell differentiation by AHR and HIF1alpha. Nat Med 21(6):638-646. https://doi.org/10.1038/nm.3868 
40. Takenaka MC, Robson S, Quintana FJ (2016) Regulation of the T Cell Response by CD39. Trends Immunol 37(7):427-439. https:// doi.org/10.1016/j.it.2016.04.009

41. Dong K, Gao ZW, Zhang HZ (2016) The role of adenosinergic pathway in human autoimmune diseases. Immunol Res 64(56):1133-1141. https://doi.org/10.1007/s12026-016-8870-2

42. Antonioli L, Blandizzi C, Pacher P, Hasko G (2013) Immunity, inflammation and cancer: a leading role for adenosine. Nat Rev Cancer 13(12):842-857. https://doi.org/10.1038/nrc3613

43. Coutinho-Silva R, Ojcius DM (2012) Role of extracellular nucleotides in the immune response against intracellular bacteria and protozoan parasites. Microbes Infect 14(14):1271-1277. https:// doi.org/10.1016/j.micinf.2012.05.009

44. Di Virgilio F, Dal Ben D, Sarti AC, Giuliani AL, Falzoni S (2017) The P2X7 Receptor in Infection and Inflammation. Immunity 47(1):15-31. https://doi.org/10.1016/j.immuni.2017.06.020

45. Paletta-Silva R, Meyer-Fernandes JR (2012) Adenosine and immune imbalance in visceral leishmaniasis: the possible role of ectonucleotidases. J Trop Med 2012:650874. https://doi.org/ $10.1155 / 2012 / 650874$

46. Paes-Vieira L, Gomes-Vieira AL, Meyer-Fernandes JR (2018) NTPDase activities: possible roles on Leishmania spp infectivity and virulence. Cell Biol Int 42(6):670-682. https://doi.org/10. 1002/cbin. 10944

47. Rai AK, Thakur CP, Velpandian T, Sharma SK, Ghosh B, Mitra DK (2011) High concentration of adenosine in human visceral leishmaniasis despite increased ADA and decreased CD73. Parasite Immunol 33(11):632-636. https://doi.org/10.1111/j.13653024.2011.01315.x

48. Vijayamahantesh AA, Dikhit MR, Mishra A, Singh AK, Das VN, Das P, Bimal S (2017) Adenosine generated by ectonucleotidases modulates the host immune system during visceral leishmaniasis. Cytokine 91:170-179. https://doi.org/10.1016/j.cyto.2017. 01.001

49. Vijayamahantesh AA, Kumar S, Dikhit MR, Jha PK, Singh AK, Sinha KK, Pandey K, Das VN, Das P, Bimal S (2016) Up regulation of $\mathrm{A} 2 \mathrm{~B}$ adenosine receptor on monocytes are crucially required for immune pathogenicity in Indian patients exposed to Leishmania donovani. Cytokine 79:38-44. https://doi.org/10. 1016/j.cyto.2015.12.016

50. Rai AK, Kumar P, Saini S, Thakur CP, Seth T, Mitra DK (2016) Increased level of soluble adenosine deaminase in bone marrow of visceral leishmaniasis patients: an inverse relation with parasite load. Acta Parasitol 61(3):645-649. https://doi.org/10.1515/ ap-2016-0087

51. Basu M, Gupta P, Dutta A, Jana K, Ukil A (2020) Increased host ATP efflux and its conversion to extracellular adenosine is crucial for establishing Leishmania infection. J Cell Sci 133(7). https:// doi.org/10.1242/jcs.239939

52. Lima MHF, Sacramento LA, Quirino GFS, Ferreira MD, Benevides L, Santana AKM, Cunha FQ, Almeida RP, Silva JS, Carregaro V (2017) Leishmania infantum Parasites Subvert the Host Inflammatory Response through the Adenosine A2A Receptor to Promote the Establishment of Infection. Front Immunol 8:815. https://doi.org/10.3389/fimmu.2017.00815

53. Chaves SP, Torres-Santos EC, Marques C, Figliuolo VR, Persechini PM, Coutinho-Silva R, Rossi-Bergmann B (2009) Modulation of $\mathrm{P} 2 \mathrm{X}(7)$ purinergic receptor in macrophages by Leishmania amazonensis and its role in parasite elimination. Microbes Infect 11(10-11):842-849. https://doi.org/10.1016/j.micinf.2009. 05.001

54. Chaves MM, Sinflorio DA, Thorstenberg ML, Martins MDA, Moreira-Souza ACA, Rangel TP, Silva CLM, Bellio M, Canetti C, Coutinho-Silva R (2019) Non-canonical NLRP3 inflammasome activation and IL-1beta signaling are necessary to L. amazonensis control mediated by $\mathrm{P} 2 \mathrm{X} 7$ receptor and leukotriene $\mathrm{B} 4$.
PLoS Pathogens 15(6):e1007887. https://doi.org/10.1371/journ al.ppat. 1007887

55. Thorstenberg ML, Rangel Ferreira MV, Amorim N, Canetti C, Morrone FB, Alves Filho JC, Coutinho-Silva R (2018) Purinergic Cooperation Between P2Y2 and P2X7 Receptors Promote Cutaneous Leishmaniasis Control: Involvement of Pannexin-1 and Leukotrienes. Front Immunol 9:1531. https://doi.org/10.3389/ fimmu.2018.01531

56. Figliuolo VR, Chaves SP, Savio LEB, Thorstenberg MLP, Machado Salles E, Takiya CM, D'Imperio-Lima MR, de Matos Guedes HL, Rossi-Bergmann B, Coutinho-Silva R (2017) The role of the P2X7 receptor in murine cutaneous leishmaniasis: aspects of inflammation and parasite control. Purinergic Signal 13(2):143-152. https://doi.org/10.1007/s11302-016-9544-1

57. de Souza MC, de Assis EA, Gomes RS, da Silva M, Ede A, Melo MN, Fietto JL, Afonso LC (2010) The influence of ectonucleotidases on Leishmania amazonensis infection and immune response in C57B/6 mice. Acta Trop 115(3):262-269. https://doi. org/10.1016/j.actatropica.2010.04.007

58. de Almeida Marques-da-Silva E, de Oliveira JC, Figueiredo AB, de Souza Lima Junior D, Carneiro CM, Rangel Fietto JL, Crocco Afonso LC (2008) Extracellular nucleotide metabolism in Leishmania: influence of adenosine in the establishment of infection. Microbes Infect 10(8):850-857. https://doi.org/10.1016/j.micinf. 2008.04.016

59. Figueiredo AB, Souza-Testasicca MC, Mineo TWP, Afonso LCC (2017) Leishmania amazonensis-Induced cAMP Triggered by Adenosine A2B Receptor Is Important to Inhibit Dendritic Cell Activation and Evade Immune Response in Infected Mice. Front Immunol 8:849. https://doi.org/10.3389/fimmu.2017.00849

60. Tonin AA, Da Silva AS, Ruchel JB, Rezer JF, Camillo G, Faccio L, Franca RT, Leal DB, Duarte MM, Vogel FF, de la Rue ML, Lopes ST (2013) E-NTPDase and E-ADA activities in lymphocytes associated with the immune response of rats experimentally infected with Toxoplasma gondii. Exp Parasitol 135(2):325-330. https://doi.org/10.1016/j.exppara.2013.07.014

61. Tonin AA, Da Silva AS, Casali EA, Silveira SS, Moritz CE, Camillo G, Flores MM, Fighera R, Thome GR, Morsch VM, Schetinger MR, Rue Mde L, Vogel FS, Lopes ST (2014) Influence of infection by Toxoplasma gondii on purine levels and E-ADA activity in the brain of mice experimentally infected mice. Exp Parasitol 142:51-58. https://doi.org/10.1016/j.exppa ra.2014.04.008

62. Bottari NB, Reichert KP, Fracasso M, Dutra A, Assmann CE, Ulrich H, Schetinger MRC, Morsch VM, Da Silva AS (2020) Neuroprotective role of resveratrol mediated by purinergic signalling in cerebral cortex of mice infected by Toxoplasma gondii. Parasitol Res. https://doi.org/10.1007/s00436-020-06795-0

63. Mahamed DA, Toussaint LE, Bynoe MS (2015) CD73-generated adenosine is critical for immune regulation during Toxoplasma gondii infection. Infect Immun 83(2):721-729. https://doi.org/ 10.1128/IAI.02536-14

64. Francois V, Shehade H, Acolty V, Preyat N, Delree P, Moser M, Oldenhove G (2015) Intestinal immunopathology is associated with decreased CD73-generated adenosine during lethal infection. Mucosal Immunol 8(4):773-784. https://doi.org/10.1038/ mi.2014.108

65. Mahamed DA, Mills JH, Egan CE, Denkers EY, Bynoe MS (2012) CD73-generated adenosine facilitates Toxoplasma gondii differentiation to long-lived tissue cysts in the central nervous system. Proc Natl Acad Sci U S A 109(40):16312-16317. https:// doi.org/10.1073/pnas.1205589109

66. Moreira-Souza ACA, Rangel TP, Silva S, Figliuolo VR, Savio LEB, Schmitz F, Takiya CM, Wyse ATS, Vommaro RC, Coutinho-Silva R (2019) Disruption of Purinergic Receptor P2X7 Signaling Increases Susceptibility to Cerebral 
Toxoplasmosis. Am J Pathol 189(4):730-738. https://doi.org/ 10.1016/j.ajpath.2019.01.001

67. Moreira-Souza ACA, Almeida-da-Silva CLC, Rangel TP, Rocha GDC, Bellio M, Zamboni DS, Vommaro RC, Coutinho-Silva R (2017) The P2X7 Receptor Mediates Toxoplasma gondii Control in Macrophages through Canonical NLRP3 Inflammasome Activation and Reactive Oxygen Species Production. Front Immunol 8:1257. https://doi.org/10.3389/fimmu.2017.01257

68. Correa G, Marques da Silva C, de Abreu Moreira-Souza AC, Vommaro RC, Coutinho-Silva R (2010) Activation of the P2X(7) receptor triggers the elimination of Toxoplasma gondii tachyzoites from infected macrophages. Microbes Infect 12(6):497504. https://doi.org/10.1016/j.micinf.2010.03.004

69. Lees MP, Fuller SJ, McLeod R, Boulter NR, Miller CM, Zakrzewski AM, Mui EJ, Witola WH, Coyne JJ, Hargrave AC, Jamieson SE, Blackwell JM, Wiley JS, Smith NC (2010) P2X7 receptormediated killing of an intracellular parasite, Toxoplasma gondii, by human and murine macrophages. J Immunol 184(12):7040 7046. https://doi.org/10.4049/jimmunol.1000012

70. Huang SW, Walker C, Pennock J, Else K, Muller W, Daniels MJ, Pellegrini C, Brough D, Lopez-Castejon G, Cruickshank SM (2017) P2X7 receptor-dependent tuning of gut epithelial responses to infection. Immunol Cell Biol 95(2):178-188. https:// doi.org/10.1038/icb.2016.75

71. Moreira-Souza AC, Marinho Y, Correa G, Santoro GF, Coutinho CM, Vommaro RC, Coutinho-Silva R (2015) Pyrimidinergic Receptor Activation Controls Toxoplasma gondii Infection in Macrophages. PLoS One 10(7):e0133502. https://doi.org/10. 1371/journal.pone.0133502

72. Moreira-Souza ACA, Coutinho-Silva R (2021) The Complexity of Purinergic Signaling During Toxoplasma Infection. Curr Top Med Chem 21(3):205-212. https://doi.org/10.2174/1568026621 999201211202533

73. Sanmarco LM, Visconti LM, Eberhardt N, Ramello MC, Ponce NE, Spitale NB, Vozza ML, Bernardi GA, Gea S, Minguez AR, Aoki MP (2016) IL-6 Improves the Nitric Oxide-Induced Cytotoxic CD8+ T Cell Dysfunction in Human Chagas Disease. Front Immunol 7:626. https://doi.org/10.3389/fimmu.2016.00626

74. Sanmarco LM, Eberhardt N, Bergero G, Quebrada Palacio LP, Adami PM, Visconti LM, Minguez AR, Hernandez-Vasquez Y, Carrera Silva EA, Morelli L, Postan M, Aoki MP (2019) Monocyte glycolysis determines CD8+ T cell functionality in human Chagas disease. JCI Insight 4(18). https://doi.org/10.1172/jci. insight. 123490

75. Eberhardt N, Sanmarco LM, Bergero G, Favaloro RR, Vigliano C, Aoki MP (2020) HIF-1alpha and CD73 expression in cardiac leukocytes correlates with the severity of myocarditis in endstage Chagas disease patients. J Leukoc Biol. https://doi.org/10. 1002/JLB.4MA0420-125R

76. Souza VD, Dos Santos JT, Cabral FL, Barbisan F, Azevedo MI, Dias Carli LF, de Avila BS, Dos Santos Jaques JA, Rosa Leal DB (2017) Evaluation of P2X7 receptor expression in peripheral lymphocytes and immune profile from patients with indeterminate form of Chagas disease. Microb Pathog 104:32-38. https:// doi.org/10.1016/j.micpath.2017.01.002

77. do Carmo GM, Doleski PH, de Sa MF, Grando TH, Bottari NB, Leal DB, Gressler LT, Henker LC, Mendes RE, Monteiro SG, Da Silva AS (2017) Purinergic enzymatic activities in lymphocytes and cardiomyocytes of mice acutely infected by Trypanosoma cruzi modulating the inflammatory responses. Exp Parasitol 175:44-50. https://doi.org/10.1016/j.exppara.2017.02.002

78. Grando TH, Baldissera MD, Do Carmo G, Oliveira CB, Santi ET, Doleski PH, Leal DBR, Stefani LM, Mendes RE, Da Silva AS, Monteiro SG (2018) Ecto-enzymes activities in splenic lymphocytes of mice experimentally infected by Trypanosoma cruzi and treated with specific avian immunoglobulins: an attempt to improve the immune response. Mol Cell Biochem 448(1-2):915. https://doi.org/10.1007/s11010-018-3308-x

79. Eberhardt N, Sanmarco LM, Bergero G, Theumer MG, Garcia MC, Ponce NE, Cano RC, Aoki MP (2020) Deficiency of CD73 activity promotes protective cardiac immunity against Trypanosoma cruzi infection but permissive environment in visceral adipose tissue. Biochim Biophys Acta 1866(3):165592. https:// doi.org/10.1016/j.bbadis.2019.165592

80. Ponce NE, Sanmarco LM, Eberhardt N, Garcia MC, Rivarola HW, Cano RC, Aoki MP (2016) CD73 Inhibition Shifts Cardiac Macrophage Polarization toward a Microbicidal Phenotype and Ameliorates the Outcome of Experimental Chagas Cardiomyopathy. J Immunol 197(3):814-823. https://doi.org/10.4049/jimmu nol.1600371

81. Santos RF, Possa MA, Bastos MS, Guedes PM, Almeida MR, Demarco R, Verjovski-Almeida S, Bahia MT, Fietto JL (2009) Influence of Ecto-nucleoside triphosphate diphosphohydrolase activity on Trypanosoma cruzi infectivity and virulence. PLoS Neg1 Trop Dis 3(3):e387. https://doi.org/10.1371/journal.pntd. 0000387

82. do Carmo GM, Doleski PH, de Sa MF, Grando TH, Azevedo MI, Manzoni AG, Leal DBR, Gressler LT, Henker LC, Mendes RE, Baldissera MD, Monteiro SG, Stefani LM, Da Silva AS (2017) Treatment with 3'-deoxyadenosine and deoxycoformycin in mice infected by Trypanosoma cruzi and its side effect on purinergic enzymes. Microb Pathog 113:51-56. https://doi.org/10.1016/j. micpath.2017.10.030

83. Borges-Pereira L, Meissner KA, Wrenger C, Garcia CRS (2017) Plasmodium falciparum GFP-E-NTPDase expression at the intraerythrocytic stages and its inhibition blocks the development of the human malaria parasite. Purinergic Signal 13(3):267-277. https://doi.org/10.1007/s11302-017-9557-4

84. Levano-Garcia J, Dluzewski AR, Markus RP, Garcia CR (2010) Purinergic signalling is involved in the malaria parasite Plasmodium falciparum invasion to red blood cells. Purinergic Signal 6(4):365-372. https://doi.org/10.1007/s11302-010-9202-y

85. Huber SM (2012) Purinoceptor signaling in malaria-infected erythrocytes. Microbes Infect 14(10):779-786. https://doi.org/ 10.1016/j.micinf.2012.04.009

86. Marin-Garcia P, Sanchez-Nogueiro J, Diez A, Leon-Otegui M, Linares M, Garcia-Palencia P, Bautista JM, Miras-Portugal MT (2009) Altered nucleotide receptor expression in a murine model of cerebral malaria. J Infect Dis 200(8):1279-1288. https://doi. org/10.1086/605896

87. Salles EM, Menezes MN, Siqueira R, Borges da Silva H, Amaral EP, Castillo-Mendez SI, Cunha I, Cassado ADA, Vieira FS, Olivieri DN, Tadokoro CE, Alvarez JM, Coutinho-Silva R, D'Imperio-Lima MR (2017) P2X7 receptor drives Th1 cell differentiation and controls the follicular helper $\mathrm{T}$ cell population to protect against Plasmodium chabaudi malaria. PLoS Pathog 13(8):e1006595. https://doi.org/10.1371/journal.ppat.1006595

88. Abel A, Steeg C, Aminkiah F, Addai-Mensah O, Addo M, Gagliani N, Casar C, Yar DD, Owusu-Dabo E, Jacobs T, Mackroth MS (2018) Differential expression pattern of co-inhibitory molecules on CD4(+) T cells in uncomplicated versus complicated malaria. Sci Rep 8(1):4789. https://doi.org/10.1038/s41598-018-22659-1

89. Allen JE, Maizels RM (2011) Diversity and dialogue in immunity to helminths. Nat Rev Immunol 11(6):375-388. https://doi.org/ $10.1038 /$ nri2992

90. de Moraes J, Geary TG (2020) FDA-Approved Antiparasitic Drugs in the 21st Century: A Success for Helminthiasis? Trends Parasitol 36(7):573-575. https://doi.org/10.1016/j.pt.2020.04. 005

91. Patel N, Wu W, Mishra PK, Chen F, Millman A, Csoka B, Koscso B, Eltzschig HK, Hasko G, Gause WC (2014) A2B adenosine receptor induces protective antihelminth type 2 
immune responses. Cell Host Microbe 15(3):339-350. https:// doi.org/10.1016/j.chom.2014.02.001

92. Lima NF, Goncalves-Lopes RM, Kruize YCM, Yazdanbakhsh M, Ferreira MU (2018) CD39 and immune regulation in a chronic helminth infection: The puzzling case of Mansonella ozzardi. PLoS Negl Trop Dis 12(3):e0006327. https://doi.org/ 10.1371/journal.pntd.0006327

93. Oliveira SD, Oliveira NF, Meyer-Fernandes JR, Savio LE, Ornelas FG, Ferreira ZS, Coutinho-Silva R, Silva CL (2016) Increased expression of NTPDases 2 and 3 in mesenteric endothelial cells during schistosomiasis favors leukocyte adhesion through P2Y1 receptors. Vascul Pharmacol 82:66-72. https://doi.org/10.1016/j.vph.2016.02.005

94. Oliveira NF, Silva CLM (2021) Unveiling the Potential of Purinergic Signaling in Schistosomiasis Treatment. Curr Top Med Chem 21(3):193-204. https://doi.org/10.2174/15680 26620666200924115113

95. Doleski PH, Mendes RE, Leal DB, Bottari NB, Piva MM, Da Silva ES, Gabriel ME, Lucca NJ, Schwertz CI, Giacomim P, Morsch VM, Schetinger MR, Baldissera MD, Da Silva AS (2016) Seric and hepatic NTPDase and 5' nucleotidase activities of rats experimentally infected by Fasciola hepatica. Parasitology 143(5):551-556. https://doi.org/10.1017/S003118201 5001882

96. Chiacchio T, Casetti R, Butera O, Vanini V, Carrara S, Girardi E, Di Mitri D, Battistini L, Martini F, Borsellino G, Goletti D (2009) Characterization of regulatory T cells identified as CD4(+)CD25(high)CD39(+) in patients with active tuberculosis. Clin Exp Immunol 156(3):463-470. https://doi.org/10.1111/j. 1365-2249.2009.03908.x

97. Boer MC, van Meijgaarden KE, Bastid J, Ottenhoff TH, Joosten SA (2013) CD39 is involved in mediating suppression by Mycobacterium bovis BCG-activated human CD8(+) CD39(+) regulatory T cells. Eur J Immunol 43(7):1925-1932. https://doi. org/10.1002/eji.201243286

98. Petit-Jentreau L, Jouvion G, Charles P, Majlessi L, Gicquel B, Tailleux L (2015) Ecto-5'-Nucleotidase (CD73) Deficiency in Mycobacterium tuberculosis-Infected Mice Enhances Neutrophil Recruitment. Infect Immun 83(9):3666-3674. https://doi.org/10. 1128/IAI.00418-15

99. Amaral EP, Ribeiro SC, Lanes VR, Almeida FM, de Andrade MR, Bomfim CC, Salles EM, Bortoluci KR, Coutinho-Silva R, Hirata MH, Alvarez JM, Lasunskaia EB, D'Imperio-Lima MR (2014) Pulmonary infection with hypervirulent Mycobacteria reveals a crucial role for the $\mathrm{P} 2 \mathrm{X} 7$ receptor in aggressive forms of tuberculosis. PLoS Pathog 10(7):e1004188. https://doi.org/10. 1371/journal.ppat.1004188

100. Santiago-Carvalho I, de Almeida-Santos G, Bomfim CCB, de Souza PC, Silva J, de Melo BMS, Amaral EP, Cione MVP, Lasunskaia E, Hirata MH, Alves-Filho JCF, Nakaya HI, Alvarez JM, D'Imperio Lima MR (2021) P2x7 Receptor Signaling Blockade Reduces Lung Inflammation and Necrosis During Severe Experimental Tuberculosis. Front Cell Infect Microbiol 11:672472. https://doi.org/10.3389/fcimb.2021.672472

101. Bomfim CCB, Amaral EP, Cassado ADA, Salles EM, do Nascimento RS, Lasunskaia E, Hirata MH, Alvarez JM, D'ImperioLima MR, (2017) P2X7 Receptor in Bone Marrow-Derived Cells Aggravates Tuberculosis Caused by Hypervirulent Mycobacterium bovis. Front Immunol 8:435. https://doi.org/10.3389/ fimmu.2017.00435

102. Santos AA Jr, Rodrigues-Junior V, Zanin RF, Borges TJ, Bonorino C, Coutinho-Silva R, Takyia CM, Santos DS, Campos MM, Morrone FB (2013) Implication of purinergic P2X7 receptor in $\mathrm{M}$. tuberculosis infection and host interaction mechanisms: a mouse model study. Immunobiology 218(8):1104-1112. https://doi.org/10.1016/j.imbio.2013.03.003
103. Matty MA, Knudsen DR, Walton EM, Beerman RW, Cronan MR, Pyle CJ, Hernandez RE, Tobin DM (2019) Potentiation of P2RX7 as a host-directed strategy for control of mycobacterial infection. eLife 8. https://doi.org/10.7554/eLife.39123

104. Fernando SL, Saunders BM, Sluyter R, Skarratt KK, Goldberg H, Marks GB, Wiley JS, Britton WJ (2007) A polymorphism in the P2X7 gene increases susceptibility to extrapulmonary tuberculosis. Am J Respir Crit Care Med 175(4):360-366. https://doi. org/10.1164/rccm.200607-970OC

105. Karmakar M, Katsnelson MA, Dubyak GR, Pearlman E (2016) Neutrophil P2X7 receptors mediate NLRP3 inflammasomedependent IL-1beta secretion in response to ATP. Nat Commun 7:10555. https://doi.org/10.1038/ncomms10555

106. Liu YH, Chang YC, Chen LK, Su PA, Ko WC, Tsai YS, Chen YH, Lai HC, Wu CY, Hung YP, Tsai PJ (2018) The ATP-P2X7 Signaling Axis Is an Essential Sentinel for Intracellular Clostridium difficile Pathogen-Induced Inflammasome Activation. Front Cell Infect Microbiol 8:84. https://doi.org/10.3389/fcimb.2018. 00084

107. Dubois-Colas N, Petit-Jentreau L, Barreiro LB, Durand S, Soubigou G, Lecointe C, Klibi J, Rezai K, Lokiec F, Coppee JY, Gicquel B, Tailleux L (2014) Extracellular adenosine triphosphate affects the response of human macrophages infected with Mycobacterium tuberculosis. J Infect Dis 210(5):824-833. https://doi.org/10.1093/infdis/jiu135

108. Amaral EP, Machado de Salles E, Barbosa Bomfim CC, Salgado RM, Almeida FM, de Souza PC, Alvarez JM, Hirata MH, Lasunskaia EB, D'Imperio-Lima MR (2019) Inhibiting Adenosine Receptor Signaling Promotes Accumulation of Effector CD4+ $\mathrm{T}$ Cells in the Lung Parenchyma During Severe Tuberculosis. J Infect Dis 219(6):964-974. https://doi.org/10.1093/infdis/jiy586

109. Olotu C, Lehmensiek F, Koch B, Kiefmann M, Riegel AK, Hammerschmidt S, Kiefmann R (2019) Streptococcus pneumoniae inhibits purinergic signaling and promotes purinergic receptor P2Y2 internalization in alveolar epithelial cells. J Biol Chem 294(34):12795-12806. https://doi.org/10.1074/jbc.RA118. 007236

110. Bou Ghanem EN, Clark S, Roggensack SE, McIver SR, Alcaide P, Haydon PG, Leong JM (2015) Extracellular Adenosine Protects against Streptococcus pneumoniae Lung Infection by Regulating Pulmonary Neutrophil Recruitment. PLoS Pathog 11(8):e1005126. https://doi.org/10.1371/journal.ppat.1005126

111. Siwapornchai N, Lee JN, Tchalla EYI, Bhalla M, Yeoh JH, Roggensack SE, Leong JM, Bou Ghanem EN (2020) Extracellular adenosine enhances the ability of PMNs to kill Streptococcus pneumoniae by inhibiting IL-10 production. J Leukoc Biol. https://doi.org/10.1002/JLB.4MA0120-115RR

112. Bhalla M, Hui Yeoh J, Lamneck C, Herring SE, Tchalla EYI, Heinzinger LR, Leong JM, Bou Ghanem EN (2020) A1 adenosine receptor signaling reduces Streptococcus pneumoniae adherence to pulmonary epithelial cells by targeting expression of platelet-activating factor receptor. Cell Microbiol 22(2):e13141. https://doi.org/10.1111/cmi.13141

113. Allard D, Charlebois R, Gilbert L, Stagg J, Chrobak P (2018) CD73-A2a adenosine receptor axis promotes innate B cell antibody responses to pneumococcal polysaccharide vaccination. PLoS One 13(1):e0191973. https://doi.org/10.1371/journal.pone. 0191973

114. Barletta KE, Cagnina RE, Burdick MD, Linden J, Mehrad B (2012) Adenosine A(2B) receptor deficiency promotes host defenses against gram-negative bacterial pneumonia. Am J Respir Crit Care Med 186(10):1044-1050. https://doi.org/10. 1164/rccm.201204-0622OC

115. Inami A, Kiyono H, Kurashima Y (2018) ATP as a Pathophysiologic Mediator of Bacteria-Host Crosstalk in the Gastrointestinal Tract. Int J Mol Sci 19(8). https://doi.org/10.3390/ijms19082371 
116. Kao DJ, Saeedi BJ, Kitzenberg D, Burney KM, Dobrinskikh E, Battista KD, Vazquez-Torres A, Colgan SP, Kominsky DJ (2017) Intestinal Epithelial Ecto-5'-Nucleotidase (CD73) Regulates Intestinal Colonization and Infection by Nontyphoidal Salmonella. Infect Immun 85(10). https://doi.org/10.1128/IAI. 01022-16

117. Alam MS, Kuo JL, Ernst PB, Derr-Castillo V, Pereira M, Gaines D, Costales M, Bigley E, Williams K (2014) Ecto-5'-nucleotidase (CD73) regulates host inflammatory responses and exacerbates murine salmonellosis. Sci Rep 4:4486. https://doi.org/10. 1038/srep04486

118. Costales MG, Alam MS, Cavanaugh C, Williams KM (2018) Extracellular adenosine produced by ecto-5'-nucleotidase (CD73) regulates macrophage pro-inflammatory responses, nitric oxide production, and favors Salmonella persistence. Nitric Oxide Biol Chem 72:7-15. https://doi.org/10.1016/j.niox.2017. 11.001

119. Proietti M, Perruzza L, Scribano D, Pellegrini G, D’Antuono R, Strati F, Raffaelli M, Gonzalez SF, Thelen M, Hardt WD, Slack E, Nicoletti M, Grassi F (2019) ATP released by intestinal bacteria limits the generation of protective $\operatorname{IgA}$ against enteropathogens. Nat Commun 10(1):250. https://doi.org/10.1038/ s41467-018-08156-z

120. Csoka B, Nemeth ZH, Szabo I, Davies DL, Varga ZV, Paloczi J, Falzoni S, Di Virgilio F, Muramatsu R, Yamashita T, Pacher P, Hasko G (2018) Macrophage P2X4 receptors augment bacterial killing and protect against sepsis. JCI Insight 3(11). https://doi. org/10.1172/jci.insight.99431

121. Belikoff BG, Hatfield S, Georgiev P, Ohta A, Lukashev D, Buras JA, Remick DG, Sitkovsky M (2011) A2B adenosine receptor blockade enhances macrophage-mediated bacterial phagocytosis and improves polymicrobial sepsis survival in mice. J Immunol 186(4):2444-2453. https://doi.org/10.4049/jimmunol.1001567

122. Nascimento DC, Viacava PR, Ferreira RG, Damaceno MA, Pineros AR, Melo PH, Donate PB, Toller-Kawahisa JE, Zoppi D, Veras FP, Peres RS, Menezes-Silva L, Caetite D, Oliveira AER, Castro IMS, Kauffenstein G, Nakaya HI, Borges MC, Zamboni DS, Fonseca DM, Paschoal JAR, Cunha TM, Quesniaux V, Linden J, Cunha FQ, Ryffel B, Alves-Filho JC (2021) Sepsis expands a CD39(+) plasmablast population that promotes immunosuppression via adenosine-mediated inhibition of macrophage antimicrobial activity. Immunity 54(9):2024-2041 e2028. https:// doi.org/10.1016/j.immuni.2021.08.005

123. Csoka B, Nemeth ZH, Toro G, Idzko M, Zech A, Koscso B, Spolarics Z, Antonioli L, Cseri K, Erdelyi K, Pacher P, Hasko G (2015) Extracellular ATP protects against sepsis through macrophage $\mathrm{P} 2 \mathrm{X} 7$ purinergic receptors by enhancing intracellular bacterial killing. FASEB J 29(9):3626-3637. https://doi.org/10. 1096/fj.15-272450

124. Lee AH, Ledderose C, Li X, Slubowski CJ, Sueyoshi K, Staudenmaier L, Bao Y, Zhang J, Junger WG (2018) Adenosine Triphosphate Release is Required for Toll-Like Receptor-Induced Monocyte/Macrophage Activation, Inflammasome Signaling, Interleukin-1beta Production, and the Host Immune Response to Infection. Crit Care Med 46(12):e1183-e1189. https://doi.org/ 10.1097/CCM.0000000000003446

125. Zhang X, Qin J, Zou J, Lv Z, Tan B, Shi J, Zhao Y, Ren H, Liu M, Qian M, Du B (2018) Extracellular ADP facilitates monocyte recruitment in bacterial infection via ERK signaling. Cell Mol Immunol 15(1):58-73. https://doi.org/10.1038/cmi.2016.56

126. Greve AS, Skals M, Fagerberg SK, Tonnus W, Ellermann-Eriksen S, Evans RJ, Linkermann A, Praetorius HA (2017) P2X1, P2X4, and P2X7 Receptor Knock Out Mice Expose Differential Outcome of Sepsis Induced by alpha-Haemolysin Producing Escherichia coli. Front Cell Infect Microbiol 7:113. https://doi. org/10.3389/fcimb.2017.00113
127. Skals M, Greve AS, Fagerberg SK, Johnsen N, Christensen MG, Praetorius HA (2019) P2X1 receptor blockers reduce the number of circulating thrombocytes and the overall survival of urosepsis with haemolysin-producing Escherichia coli. Purinergic Signal 15(2):265-276. https://doi.org/10.1007/ s11302-019-09658-1

128. Fagerberg SK, Jakobsen MR, Skals M, Praetorius HA (2016) Inhibition of P2X Receptors Protects Human Monocytes against Damage by Leukotoxin from Aggregatibacter actinomycetemcomitans and alpha-Hemolysin from Escherichia coli. Infect Immun 84(11):3114-3130. https://doi.org/10.1128/IAI.00674-16

129. Perez-Flores G, Hernandez-Silva C, Gutierrez-Escobedo G, De Las PA, Castano I, Arreola J, Perez-Cornejo P (2016) P2X7 from j774 murine macrophages acts as a scavenger receptor for bacteria but not yeast. Biochem Biophys Res Commun 481(1-2):1924. https://doi.org/10.1016/j.bbrc.2016.11.027

130. Tang X, Basavarajappa D, Haeggstrom JZ, Wan M (2015) P2X7 Receptor Regulates Internalization of Antimicrobial Peptide LL-37 by Human Macrophages That Promotes Intracellular Pathogen Clearance. J Immunol 195(3):1191-1201. https://doi. org/10.4049/jimmunol.1402845

131. Schwiering M, Husmann M, Hellmann N (2017) P2X-Receptor Antagonists Inhibit the Interaction of S. aureus Hemolysin A with Membranes. Toxins 9(10). https://doi.org/10.3390/toxin s9100332

132. Nagahama M, Seike S, Shirai H, Takagishi T, Kobayashi K, Takehara M (1850) Sakurai J (2015) Role of P2X7 receptor in Clostridium perfringens beta-toxin-mediated cellular injury. Biochem Biophys Acta 11:2159-2167. https://doi.org/10.1016/j. bbagen.2015.08.011

133. Thammavongsa V, Kern JW, Missiakas DM, Schneewind O (2009) Staphylococcus aureus synthesizes adenosine to escape host immune responses. J Exp Med 206(11):2417-2427. https:// doi.org/10.1084/jem.20090097

134. Paoletti A, Raza SQ, Voisin L, Law F, Pipoli da Fonseca J, Caillet M, Kroemer G, Perfettini JL (2012) Multifaceted roles of purinergic receptors in viral infection. Microbes Infect 14(14):1278-1283. https://doi.org/10.1016/j.micinf.2012.05.010

135. Pacheco PA, Faria RX, Ferreira LG, Paixao IC (2014) Putative roles of purinergic signaling in human immunodeficiency virus-1 infection. Biol Direct 9:21. https://doi.org/10.1186/ 1745-6150-9-21

136. Nikolova M, Carriere M, Jenabian MA, Limou S, Younas M, Kok A, Hue S, Seddiki N, Hulin A, Delaneau O, Schuitemaker H, Herbeck JT, Mullins JI, Muhtarova M, Bensussan A, Zagury JF, Lelievre JD, Levy Y (2011) CD39/adenosine pathway is involved in AIDS progression. PLoS Pathog 7(7):e1002110. https://doi. org/10.1371/journal.ppat.1002110

137. Jenabian MA, Seddiki N, Yatim A, Carriere M, Hulin A, Younas M, Ghadimi E, Kok A, Routy JP, Tremblay A, Sevigny J, Lelievre JD, Levy Y (2013) Regulatory T cells negatively affect IL-2 production of effector T cells through CD39/adenosine pathway in HIV infection. PLoS Pathog 9(4):e1003319. https:// doi.org/10.1371/journal.ppat.1003319

138. Song JW, Huang HH, Zhang C, Yang HG, Zhang JY, Xu RN, Jin L, Shi M, Wang FS, Jiao YM (2019) Expression of CD39 Is Correlated With HIV DNA Levels in Naive Tregs in Chronically Infected ART Naive Patients. Front Immunol 10:2465. https:// doi.org/10.3389/fimmu.2019.02465

139. Dierks P, Wroblewski R, Eberhard JM, Martrus G, Degen O, Hertling S, Schmiedel S, Lunemann S, Hufner A, Lohse AW, Altfeld M, van Lunzen J, Schulze Zur Wiesch J (2017) Brief Report: Increased Frequency of CD39+ CD56bright Natural Killer Cells in HIV-1 Infection Correlates With Immune Activation and Disease Progression. J Acquir Immune Defic Syndr 74(4):467-472. https://doi.org/10.1097/QAI.0000000000001266 
140. Burton CT, Westrop SJ, Eccles-James I, Boasso A, Nelson MR, Bower M, Imami N (2011) Altered phenotype of regulatory $\mathrm{T}$ cells associated with lack of human immunodeficiency virus (HIV)-1-specific suppressive function. Clin Exp Immunol 166(2):191-200. https://doi.org/10.1111/j.1365-2249.2011. 04451.x

141. Schuler PJ, Macatangay BJ, Saze Z, Jackson EK, Riddler SA, Buchanan WG, Hilldorfer BB, Mellors JW, Whiteside TL, Rinaldo CR (2013) CD4(+)CD73(+) T cells are associated with lower $\mathrm{T}$-cell activation and $\mathrm{C}$ reactive protein levels and are depleted in HIV-1 infection regardless of viral suppression. AIDS 27(10):1545-1555. https://doi.org/10.1097/QAD.0b013 e328360c7f3

142. Toth I, Le AQ, Hartjen P, Thomssen A, Matzat V, Lehmann C, Scheurich C, Beisel C, Busch P, Degen O, Lohse AW, Eiermann T, Fatkenheuer G, Meyer-Olson D, Bockhorn M, Hauber J, van Lunzen J, Schulze Zur Wiesch J (2013) Decreased frequency of CD73+CD8+ T cells of HIV-infected patients correlates with immune activation and T cell exhaustion. J Leukoc Biol 94(4):551-561. https://doi.org/10.1189/jlb.0113018

143. Carriere M, Lacabaratz C, Kok A, Benne C, Jenabian MA, Casartelli N, Hue S, Hocqueloux L, Lelievre JD, Levy Y (2014) HIV "elite controllers" are characterized by a high frequency of memory CD8 + CD73 + T cells involved in the antigen-specific CD8+ T-cell response. J Infect Dis 209(9):1321-1330. https:// doi.org/10.1093/infdis/jit643

144. Kim ES, Ackermann C, Toth I, Dierks P, Eberhard JM, Wroblewski R, Scherg F, Geyer M, Schmidt RE, Beisel C, Bockhorn M, Haag F, van Lunzen J, Schulze Zur Wiesch J (2017) Down-regulation of CD73 on B cells of patients with viremic HIV correlates with B cell activation and disease progression. J Leukoc Biol 101(5):1263-1271. https://doi.org/10.1189/jlb. 5A0816-346R

145. Casanova V, Naval-Macabuhay I, Massanella M, Rodriguez-Garcia M, Blanco J, Gatell JM, Garcia F, Gallart T, Lluis C, Mallol J, Franco R, Climent N, McCormick PJ (2012) Adenosine deaminase enhances the immunogenicity of human dendritic cells from healthy and HIV-infected individuals. PLoS One 7(12):e51287. https://doi.org/10.1371/journal.pone.0051287

146. Naval-Macabuhay I, Casanova V, Navarro G, Garcia F, Leon A, Miralles L, Rovira C, Martinez-Navio JM, Gallart T, Mallol J, Gatell JM, Lluis C, Franco R, McCormick PJ, Climent N (2016) Adenosine deaminase regulates Treg expression in autologous T cell-dendritic cell cocultures from patients infected with HIV1. J Leukoc Biol 99(2):349-359. https://doi.org/10.1189/jlb. 3A1214-580RR

147. Barat C, Gilbert C, Imbeault M, Tremblay MJ (2008) Extracellular ATP reduces HIV-1 transfer from immature dendritic cells to CD4+ T lymphocytes. Retrovirology 5:30. https://doi.org/10. 1186/1742-4690-5-30

148. Tardif V, Muir R, Cubas R, Chakhtoura M, Wilkinson P, Metcalf T, Herro R, Haddad EK (2019) Adenosine deaminase-1 delineates human follicular helper $\mathrm{T}$ cell function and is altered with HIV. Nat Commun 10(1):823. https://doi.org/10.1038/ s41467-019-08801-1

149 Hixson EA, Borker PV, Jackson EK, Macatangay BJ (2021) The Adenosine Pathway and Human Immunodeficiency VirusAssociated Inflammation. Open Forum Infect Dis 8(9):ofa396. https://doi.org/10.1093/ofid/ofab396

150. Orellana JA, Velasquez S, Williams DW, Saez JC, Berman JW, Eugenin EA (2013) Pannexin1 hemichannels are critical for HIV infection of human primary CD4+ T lymphocytes. J Leukoc Biol 94(3):399-407. https://doi.org/10.1189/jlb.0512249
151. Seror C, Melki MT, Subra F, Raza SQ, Bras M, Saidi H, Nardacci R, Voisin L, Paoletti A, Law F, Martins I, Amendola A, AbdulSater AA, Ciccosanti F, Delelis O, Niedergang F, Thierry S, Said-Sadier N, Lamaze C, Metivier D, Estaquier J, Fimia GM, Falasca L, Casetti R, Modjtahedi N, Kanellopoulos J, Mouscadet JF, Ojcius DM, Piacentini M, Gougeon ML, Kroemer G, Perfettini JL (2011) Extracellular ATP acts on P2Y2 purinergic receptors to facilitate HIV-1 infection. J Exp Med 208(9):1823-1834. https://doi.org/10.1084/jem.20101805

152. Freeman TL, Swartz TH (2020) Purinergic Receptors: Elucidating the Role of these Immune Mediators in HIV-1 Fusion. Viruses 12(3). https://doi.org/10.3390/v12030290

153. Hazleton JE, Berman JW, Eugenin EA (2012) Purinergic receptors are required for HIV-1 infection of primary human macrophages. J Immunol 188(9):4488-4495. https://doi.org/10.4049/ jimmunol.1102482

154. Schachter J, Delgado KV, Barreto-de-Souza V, Bou-Habib DC, Persechini PM, Meyer-Fernandes JR (2015) Inhibition of ectoATPase activities impairs HIV-1 infection of macrophages. Immunobiology 220(5):589-596. https://doi.org/10.1016/j. imbio.2014.12.004

155. Soare AY, Durham ND, Gopal R, Tweel B, Hoffman KW, Brown JA, O'Brien M, Bhardwaj N, Lim JK, Chen BK, Swartz TH (2019) P2X Antagonists Inhibit HIV-1 Productive Infection and Inflammatory Cytokines Interleukin-10 (IL-10) and IL-1beta in a Human Tonsil Explant Model. J Virol 93(1). https://doi.org/10. 1128/JVI.01186-18

156. Giroud C, Marin M, Hammonds J, Spearman P, Melikyan GB (2015) P2X1 Receptor Antagonists Inhibit HIV-1 Fusion by Blocking Virus-Coreceptor Interactions. J Virol 89(18):93689382. https://doi.org/10.1128/JVI.01178-15

157. Swartz TH, Esposito AM, Durham ND, Hartmann BM, Chen BK (2014) P2X-selective purinergic antagonists are strong inhibitors of HIV-1 fusion during both cell-to-cell and cell-free infection. J Virol 88(19):11504-11515. https://doi.org/10.1128/JVI. 01158-14

158. Zhang $\mathrm{C}$, He H, Wang L, Zhang N, Huang H, Xiong Q, Yan Y, Wu N, Ren H, Han H, Liu M, Qian M, Du B (2017) Virus-Triggered ATP Release Limits Viral Replication through Facilitating IFN-beta Production in a P2X7-Dependent Manner. J Immunol 199(4):1372-1381. https://doi.org/10.4049/jimmunol.1700187

159. Lee BH, Hwang DM, Palaniyar N, Grinstein S, Philpott DJ, Hu J (2012) Activation of P2X(7) receptor by ATP plays an important role in regulating inflammatory responses during acute viral infection. PLoS One 7(4):e35812. https://doi.org/10.1371/journ al.pone. 0035812

160. Leyva-Grado VH, Ermler ME, Schotsaert M, Gonzalez MG, Gillespie V, Lim JK, Garcia-Sastre A (2017) Contribution of the Purinergic Receptor P2X7 to Development of Lung Immunopathology during Influenza Virus Infection. mBio 8(2). https:// doi.org/10.1128/mBio.00229-17

161. Vanderstocken G, Van de Paar E, Robaye B, di Pietrantonio L, Bondue B, Boeynaems JM, Desmecht D, Communi D (2012) Protective role of $\mathrm{P} 2 \mathrm{Y} 2$ receptor against lung infection induced by pneumonia virus of mice. PLoS One 7(11):e50385. https:// doi.org/10.1371/journal.pone.0050385

162. Aeffner F, Woods PS, Davis IC (2015) Ecto-5'-nucleotidase CD73 modulates the innate immune response to influenza infection but is not required for development of influenzainduced acute lung injury. Am J Physiol Lung Cell Mol Physiol 309(11):L1313-1322. https://doi.org/10.1152/ajplung.00130. 2015 
163. Woods PS, Doolittle LM, Hickman-Davis JM, Davis IC (2018) ATP catabolism by tissue nonspecific alkaline phosphatase contributes to development of ARDS in influenza-infected mice. Am J Physiol Lung Cell Mol Physiol 314(1):L83-L92. https://doi. org/10.1152/ajplung.00149.2017

164. Ahmadi P, Hartjen P, Kohsar M, Kummer S, Schmiedel S, Bockmann JH, Fathi A, Huber S, Haag F, Schulze Zur Wiesch J (2020) Defining the CD39/CD73 Axis in SARS-CoV-2 Infection: The CD73(-) Phenotype Identifies Polyfunctional Cytotoxic Lymphocytes. Cells 9(8). https://doi.org/10.3390/cells9081750

165. Ribeiro DE, Oliveira-Giacomelli A, Glaser T, Arnaud-Sampaio VF, Andrejew R, Dieckmann L, Baranova J, Lameu C, Ratajczak MZ, Ulrich H (2021) Hyperactivation of P2X7 receptors as a culprit of COVID-19 neuropathology. Mol Psychiatry 26(4):10441059. https://doi.org/10.1038/s41380-020-00965-3

166. Franciosi MLM, Lima MDM, Schetinger MRC, Cardoso AM (2021) Possible role of purinergic signaling in COVID-19. Mol Cell Biochem 476(8):2891-2898. https://doi.org/10.1007/ s11010-021-04130-4

167. Simoes JLB, Bagatini MD (2021) Purinergic Signaling of ATP in COVID-19 Associated Guillain-Barre Syndrome. J Neuroimmune Pharmacol 16(1):48-58. https://doi.org/10.1007/ s11481-020-09980-1

168. Corrêa G, Lindenberg C de A, Fernades-Santos C, Gandini M, Paiva FP, Coutinho-Silva R, Kubelka CF (2016) The purinergic receptor $\mathrm{P} 2 \mathrm{X} 7$ role in control of Dengue virus-2 infection and cytokine/chemokine production in infected human monocytes. Immunobiology 221(7):794-802. https://doi.org/10.1016/j. imbio.2016.02.003

169. Tsai CY, Liong KH, Gunalan MG, Li N, Lim DS, Fisher DA, MacAry PA, Leo YS, Wong SC, Puan KJ, Wong SB (2015) Type I IFNs and IL-18 regulate the antiviral response of primary human gammadelta $\mathrm{T}$ cells against dendritic cells infected with Dengue virus. J Immunol 194(8):3890-3900. https://doi.org/10. 4049/jimmunol.1303343

170. Patkar C, Giaya K, Libraty DH (2013) Dengue virus type 2 modulates endothelial barrier function through CD73. Am J Trop Med Hyg 88(1):89-94. https://doi.org/10.4269/ajtmh.2012. 12-0474

171. Taylor JM, Han Z (2010) Purinergic receptor functionality is necessary for infection of human hepatocytes by hepatitis delta virus and hepatitis B virus. PLoS One 5(12):e15784. https://doi. org/10.1371/journal.pone.0015784

172. Ashraf W, Manzoor S, Ashraf J, Ahmed QL, Khalid M, Tariq M, Imran M, Aziz H (2013) Transcript analysis of P2X receptors in PBMCs of chronic HCV patients: an insight into antiviral treatment response and $\mathrm{HCV}$-induced pathogenesis. Viral Immunol 26(5):343-350. https://doi.org/10.1089/vim.2013.0044

173. Manzoor S, Akhtar U, Naseem S, Khalid M, Mazhar M, Parvaiz F, Khaliq S (2016) Ionotropic Purinergic Receptors P2X4 and P2X7: Proviral or Antiviral? An Insight into P2X Receptor Signaling and Hepatitis C Virus Infection. Viral Immunol 29(7):401-408. https://doi.org/10.1089/vim.2016.0008

174. Khalid M, Manzoor S, Ahmad H, Asif A, Bangash TA, Latif A, Jaleel S (2018) Purinoceptor expression in hepatocellular virus
(HCV)-induced and non-HCV hepatocellular carcinoma: an insight into the proviral role of the P2X4 receptor. Mol Biol Rep 45(6):2625-2630. https://doi.org/10.1007/s11033-018-4432-0

175. Tang Y, Jiang L, Zheng Y, Ni B, Wu Y (2012) Expression of $\mathrm{CD} 39$ on FoxP3+ T regulatory cells correlates with progression of HBV infection. BMC Immunol 13:17. https://doi.org/10.1186/ 1471-2172-13-17

176. Zoppellaro C, Bin A, Brun P, Banzato S, Macchi V, Castagliuolo I, Giron MC (2013) Adenosine-mediated enteric neuromuscular function is affected during herpes simplex virus type 1 infection of rat enteric nervous system. PLoS One 8(8):e72648. https://doi. org/10.1371/journal.pone.0072648

177. Kan Y, Okabayashi T, Yokota S, Yamamoto S, Fujii N, Yamashita $T$ (2012) Imiquimod suppresses propagation of herpes simplex virus 1 by upregulation of cystatin A via the adenosine receptor A1 pathway. J Virol 86(19):10338-10346. https://doi. org/10.1128/JVI.01196-12

178. Chen S, Shenk T, Nogalski MT (2019) P2Y2 purinergic receptor modulates virus yield, calcium homeostasis, and cell motility in human cytomegalovirus-infected cells. Proc Natl Acad Sci U S A 116(38):18971-18982. https://doi.org/10.1073/pnas.1907562116

179. Choi SJ, Ryu E, Lee S, Huh S, Shin YS, Kang BW, Kim JG, Cho H, Kang H (2019) Adenosine Induces EBV Lytic Reactivation through ADORA1 in EBV-Associated Gastric Carcinoma. Int J Mol Sci 20(6). https://doi.org/10.3390/ijms20061286

180. Yang YC, Chang TY, Chen TC, Lin WS, Chang SC, Lee YJ (2016) Functional variant of the P2X7 receptor gene is associated with human papillomavirus-16 positive cervical squamous cell carcinoma. Oncotarget 7(50):82798-82803. https://doi.org/10. 18632/oncotarget. 12636

181. Antonioli L, Blandizzi C, Pacher P, Hasko G (2019) The Purinergic System as a Pharmacological Target for the Treatment of Immune-Mediated Inflammatory Diseases. Pharmacol Rev 71(3):345-382. https://doi.org/10.1124/pr.117.014878

182. Savio LEB, Coutinho-Silva R (2016) Purinergic signaling in infection and autoimmune disease. Biomed J 39(5):304-305. https://doi.org/10.1016/j.bj.2016.09.002

183. Allard B, Longhi MS, Robson SC, Stagg J (2017) The ectonucleotidases CD39 and CD73: Novel checkpoint inhibitor targets. Immunol Rev 276(1):121-144. https://doi.org/10.1111/imr. 12528

184. Sek K, Molck C, Stewart GD, Kats L, Darcy PK, Beavis PA (2018) Targeting Adenosine Receptor Signaling in Cancer Immunotherapy. Int J Mol Sci 19(12). https://doi.org/10.3390/ijms1 9123837

185. Burnstock G (2017) Purinergic Signalling: Therapeutic Developments. Front Pharmacol 8:661. https://doi.org/10.3389/fphar. 2017.00661

186. Burnstock $\mathrm{G}$ (2018) The therapeutic potential of purinergic signalling. Biochem Pharmacol 151:157-165. https://doi.org/10. 1016/j.bcp.2017.07.016

187. Azambuja JH, Ludwig N, Braganhol E, Whiteside TL (2019) Inhibition of the Adenosinergic Pathway in Cancer Rejuvenates Innate and Adaptive Immunity. Int J Mol Sci 20(22). https://doi. org/10.3390/ijms20225698 
188. Kumar V, Sharma A (2009) Adenosine: an endogenous modulator of innate immune system with therapeutic potential. Eur J Pharmacol 616(1-3):7-15. https://doi.org/10.1016/j.ejphar.2009. 05.005

189. Pacheco PAF, Dantas LP, Ferreira LGB, Faria RX (2018) Purinergic receptors and neglected tropical diseases: why ignore purinergic signaling in the search for new molecular targets? J Bioenergy Biomembr 50(4):307-313. https://doi.org/10.1007/ s10863-018-9761-0

190. da Silva W, da Rocha TN, de Melo AJ, da Silva VHF, de Souza ACA, Ribeiro IC, de Oliveira TA, de Souza LA, Andrade LKR, de Moraes JVB, Diogo MA, de Castro RB, Poleto MD, Afonso LCC, Fietto JLR (2021) ENTPDases from Pathogenic Trypanosomatids and Purinergic Signaling: Shedding Light towards Biotechnological Applications. Curr Top Med Chem 21(3):213-226. https://doi.org/10.2174/1568026620666201005125146

Publisher's note Springer Nature remains neutral with regard to jurisdictional claims in published maps and institutional affiliations.

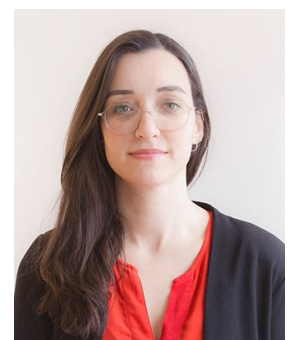

Natalia Eberhardt, Ph.D. completed her $\mathrm{Ph} . \mathrm{D}$. in immunology from the University of Cordoba, Argentina, in 2019. Her doctoral work focused on understanding the regulation of cardiac immune response by the purinergic system and its contribution to Chagas cardiomyopathy development. She joined the Giannarelli Lab (NYU School of Medicine, NYC) as a postdoctoral fellow in 2020. Her current project includes investigating immune mechanisms that finely control the T-cell effector functions and sustain chronic inflammation in atherosclerotic disease. 